Operations Management

Elsevier Editorial System(tm) for Journal of

Manuscript Draft

Manuscript Number: OPEMAN-D-15-00546R2

Title: The Impact of Firms' Social Media Initiatives on Operational Efficiency and Innovativeness

Article Type: Full Length Article

Keywords: social media; operational efficiency; innovativeness

Corresponding Author: Prof. Andy C. L. Yeung, Ph.D.

Corresponding Author's Institution: The Hong Kong Polytechnic University

First Author: Hugo K. S. Lam, Ph.D.

Order of Authors: Hugo K. S. Lam, Ph.D.; Andy C. L. Yeung, Ph.D.; T. C. Edwin Cheng, Ph.D.

Abstract: Social media have been increasingly adopted for organizational purposes but their operational implications are not well understood. Firms' social media initiatives might facilitate information flow and knowledge sharing within and across organizations, strengthening firmcustomer interaction, and improving internal and external collaboration. In this research we empirically examine the impact of social media initiatives on firms' operational efficiency and innovativeness. Taking the resource-based view of firms' information capability, we consider firms' social media initiatives as strategic resources for operational improvement. We posit that firms' social media initiatives enhance dynamic knowledge-sharing routines through an information-rich social network, leading to both operational efficiency and innovativeness. collecting secondary data in a longitudinal setting from multiple sources, we construct dynamic panel data (DPD) models. Based on system generalized method of moments (GMM) estimation, we show that firms' social media initiatives improve operational efficiency and innovativeness. We identify the importance of an information-rich social network to the creation of knowledge-based advantage through firms' social media initiatives, and discuss the theoretical and managerial implications from the perspective of operations management. 


\title{
The Impact of Firms' Social Media Initiatives on Operational Efficiency and Innovativeness
}

\begin{abstract}
Social media have been increasingly adopted for organizational purposes but their operational implications are not well understood. Firms' social media initiatives might facilitate information flow and knowledge sharing within and across organizations, strengthening firm-customer interaction, and improving internal and external collaboration. In this research we empirically examine the impact of social media initiatives on firms' operational efficiency and innovativeness. Taking the resource-based view of firms' information capability, we consider firms' social media initiatives as strategic resources for operational improvement. We posit that firms' social media initiatives enhance dynamic knowledge-sharing routines through an information-rich social network, leading to both operational efficiency and innovativeness. Collecting secondary data in a longitudinal setting from multiple sources, we construct dynamic panel data (DPD) models. Based on system generalized method of moments (GMM) estimation, we show that firms' social media initiatives improve operational efficiency and innovativeness. We identify the importance of an information-rich social network to the creation of knowledge-based advantage through firms' social media initiatives, and discuss the theoretical and managerial implications from the perspective of operations management.
\end{abstract}

Keywords: social media; operational efficiency; innovativeness 


\section{Introduction}

Marching beyond personal or individual usage, social media have been increasingly adopted for organizational purposes such as operations and innovation management (Kiron et al., 2012). For instance, Starbucks has launched a social media platform called My Starbucks Idea to enable customers to participate in developing new drinks and flavors (Gallaugher and Ransbotham, 2010), and Caterpillar has adopted the Spredfast social media platform to facilitate coordination and collaboration across its internal departments and extended dealer network (PR Newswire, 2012). Recently, Kane et al. (2014) reported that $87 \%$ of maturing companies used social media to spur innovation while $60 \%$ integrated social media into their operations.

In fact, making strategic use of social media is at the top of the agenda for many organizations. Firms are now considering social media as an approach to amplify the word of mouth of their products, a channel to keep customers in contact, and a chance for direct sales and marketing (Gamboa and Gonçalves, 2014). While the importance of listening to customers has been well recognized, especially under the quality management principle, the rapid-developing social media technologies empower customers, strengthen firm-customer connection, and provide opportunities for operational improvement. For example, it was reported that large banks such as the Bank of America actively turned "online rants into compliments" and used social media to "reach out to clients or employees to head off problems" (Epstein, 2011, p. P9). Tapping text analytic methods to search for customer feedback, social media technologies enabled Wendy's to "report on customer experiences down to the store level within minutes" (Henschen, 2010). Social media have also changed the way in which individuals contact and learn about firms' offerings (Rishika et al., 2013). A firm's capability in facilitating information flow quickly through customer feedback and interaction is increasingly critical for business success.

Social media provide a platform for experience sharing, knowledge accumulation, and organizational learning (Nguyen et al., 2015). Corporate discussion forums (CDS) of organizations enable firms to gather a particular group of customers and other stakeholders with diverse backgrounds to discuss organization-specific issues, work collaboratively, and create new ideas. The 
term "open innovation" refers to a system whereby innovation is not primarily undertaken by a specific research unit, but rather is developed publicly (Martini et al., 2014). By allowing ideas to generate dynamically through social networks and clusters, firms enjoy collective inventions characterized by fast knowledge accumulation and rapid product development rates.

Social media also enhance knowledge sharing within organizations through social networking of internal staff members (Cao et al., 2015). Internal social media platforms enhance effective organizational communication by providing employees across geographical locations with a forum for posting job updates, asking questions, and sharing best practices. Intra-organizational communication facilitates information exchange and knowledge assimilation, improving cross-functional coordination and management. For example, GE relied on Colab, its internal social media platform, to connect its 60,000 knowledge workers worldwide, enabling them to get "together to solve problems and share best practices" (Goulart, 2012, p. 14). Facilitating information flow across organizations, social media also allows business partners to have unprecedented access to vast volumes of external knowledge sources, improving business intelligence across organizations and supply chain networks.

Although anecdotal evidence suggests that firms can benefit from their social media efforts in terms of operational efficiency and innovativeness improvement (Cecere, 2010; Kane et al., 2014), some practitioners worry about the potential drawbacks of adopting social media in organizations. For instance, too much social interaction on social media may disrupt work and distract employees from work-related communication, resulting in lower productivity (Leonardi et al., 2013); outflow of firms' information and knowledge to external social networks via social media may lead to leakage of confidential information and trade secrets, hurting firms' intellectual property and innovativeness (Molok et al., 2010). On the other hand, while the emerging social media phenomenon has attracted much research attention in recent years (Aral et al., 2013; Fader and Winer, 2012), little empirical evidence is documented in the literature about the impact of firms' social media initiatives on operational efficiency and innovativeness. Our research fills this research gap.

We argue that social media facilitate firms' information flow and knowledge sharing across internal and external social networks, which enhance internal and external collaboration, and allow 
firms to be more customer-oriented, contributing to operational efficiency and innovativeness improvement. By strategically enhancing information flow and knowledge acquisition, firms are likely to improve their capability in new product/service development and idea generation, leading to enhancement in both efficiency and creativity ( $\mathrm{Li}$ et al., 2014). To test our hypotheses, we collected longitudinal performance data from 2006 to 2012 and examined firms' social media initiatives in 281 organizations between 2006 and 2011 (Section 3 provides the details). Using system generalized method of moments (GMM) estimation to analyze the data, we show that social media initiatives improve firms' operational efficiency and innovativeness.

\section{Theoretical background and hypothesis development}

\subsection{Social media initiatives}

Social media are "a group of Internet-based applications that build on the ideological and technological foundations of Web 2.0, and that allow the creation and exchange of User Generated Content" (Kaplan and Haenlein, 2010, p. 61). With a view to capitalizing on the content generated by their stakeholders (particularly existing and potential customers), firms increasingly adopt social media for various organizational purposes such as marketing, operations, and innovation management (Kiron et al., 2012), which we refer to as social media initiatives in this research. With reference to prior studies (e.g., Kiron et al., 2013; Kane et al., 2014), we classify firms' social media initiatives into six categories based on their different business objectives as follows: 1) Employee collaboration and internal communication, 2) Interfirm cooperation and supply chain management, 3) New product development and idea generation, 4) Public relations and corporate social responsibility, 5) Customer service and customer relationship management, and 6) Sales and marketing. Table 1 lists some examples in each category extracted from our sample.

--- Table 1 about here ---

Although researchers have been paying increasing attention to the emerging social media phenomenon in recent years, the existing research focuses on studying the effects of social media users' actions (Aral et al., 2013), rather than the outcomes of firms' strategic use of social media (i.e., social media initiatives). For instance, Forman et al. (2008) investigated the impact of 
consumer-generated product reviews in an online community on firms' product sale. Luo et al. (2013) studied the ability of consumers' online ratings and blog posts to predict firms' equity value. Even though some researchers have begun to examine firms' social media initiatives directly (Gu and Ye, 2014; Rishika et al., 2013; Wu, 2013), they focus on the consequences of firms' social media initiatives at the individual user level, rather than their impacts at the firm level. For instance, Wu (2013) analyzed how a firm's adoption of social networking tool affects the work performance and job security of individual employees. Gu and Ye (2014) examined how a firm's responses to customer comments on social media affect the satisfaction of individual customers. Our research is an initial attempt to investigate the impact of social media initiatives at the firm level.

\subsection{Social media initiatives, information capability and competitive advantage}

In a rapid-changing and fast-moving business environment, the traditional static approach of knowledge-warehouse deployment has undergone a paradigm shift towards a dynamic capability in capturing knowledge through high-velocity, high-volume information flow (Kankanhalli et al., 2005). Organizations that are able to make use of external and internal information movements and big data are likely to have knowledge-based advantage over their competitors. Social media, which empower multi-way communication between organizations and their stakeholders in an efficient and cost-effective manner (Chua and Banerjee, 2013), is considered as a strategic approach to foster knowledge exchange among individuals and organizations, advancing organizational learning and knowledge management, thus yielding a competitive edge (Thomas and Akdere, 2013).

More generally, the impact of social media initiatives on firm performance can be understood through the resource-based view (RBV) of a firm's information capability. RBV suggests that firms are able to create competitive advantage through a complex, bundled set of resources that are rare, valuable, inimitable, and non-substitutable (Barney, 1991; Hitt et al., 2016b). Hitt et al (2016b) argued that $\mathrm{RBV}$ has become more important for $\mathrm{OM}$ research as $\mathrm{OM}$ researchers are increasingly focused on a collective of organizational routines within and across firms that reinforce each other to create competitive advantage. Although information technology by itself rarely contributes directly to a firm's sustained competitive advantage, it forms part of the firm's operationally complex routines and 
capabilities (Wade and Hulland, 2004). Barney's (1991) seminal research considered a firm's strategic resources as a package of assets, attributes, information, and knowledge that can be sophisticatedly deployed to conceive of and implement organizational strategy, leading to competitive advantage.

A number of $\mathrm{OM}$ researchers have shown that interpersonal and interfirm relationships developed through information technology and online information capability enhance a firm's operational capabilities (Johnson et al., 2007; Vaidyanathan and Devaraj, 2008). In particular, relation-specific assets and knowledge-sharing routines are idiosyncratic, and socially and operationally complex (Johnson et al., 2007), contributing directly to competitive advantage. Wade and Hulland (2004) delineated that a firm's information capacity contributes to competitive edge creation through outside-in capabilities and spanning capabilities. Outside-in capabilities refer to the development of externally-oriented business intelligence and relationships, placing an emphasis on anticipating market trends, responding to customer requirements, and understanding competitive landscapes. Spanning capabilities refer to information alignments internally and externally, spanning the traditional knowledge gaps that exist between departments, across firms, and along the supply chain.

Social network theory suggests that information-rich social networks that bridge distinct parties and span "structural holes" are critical to organizations (Aral et al., 2012). Informal communication networks through social media are critical to knowledge flow between individuals ( $\mathrm{Wu}, 2013)$. Research in information systems (Dou et al., 2013; Wu, 2013) and organization science (Dahlander and Frederiksen, 2012; Tuertscher et al., 2014) shows that social media technologies can supplement an established social structure, leading to a new, information-rich system for knowledge brokerage and dissemination (Leonardi, 2007). Ample evidence suggests that employees who are positioned in an information-rich social network and serve as an information broker for diversified groups of contacts from distinct parts of organizational networks are likely to be both more productive and innovative (Aral et al., 2012; Wu, 2013).

In fact, the strategic importance of information flow and knowledge sharing to competitive advantage is well recognized in various business disciplines (see, e.g., Cousins and Menguc, 2006; 
Tsai, 2001; Tanriverdi, 2005). Through social media initiatives, a firm's information capability is enhanced through personal and organizational social networks (Leonardi, 2007). Informational processing theory asserts that a firm' major task is to handle, gather, and act on data as they emerge (Hult et al., 2004), and the best organizational structure is to follow the information processing requirements (Leonardi, 2007). Nevertheless, organizations are traditionally structured according to functional units. Such a "silo" organizational structure often impedes communication across geographically dispersed business entities. Social media technologies strengthen the information flow through the traditional organizational structure, promoting the formation of a powerful information-sharing channel and advice-seeking network.

\subsection{The impact of social media on operational efficiency and innovativeness}

A firm's social media initiatives are likely to positively influence its operational efficiency. A firm's relative performance in operational efficiency depends on its resources, routines, and capabilities. Resources refer to productive assets that are both tangible and intangible, routines are organizational processes that utilize a complex set of resources, and capabilities are the proficiency in deploying a dynamic bundle of routines (Peng et al., 2008). Both routines and capabilities are socially complex and operationally sophisticated. They are embedded in dynamic interfaces of multiple vibrant knowledge sources within and outside organizations. As a result, a firm's capability in achieving efficient operations is established through dynamic information and knowledge exchange among individuals, with customers, and across institutions (Kusunoki et al., 1998; Peng et al., 2008).

The traditional learning curve model in OM research suggests that knowledge is developed through individual and collective experience accumulation (Yli-Renko et al., 2001). Networks of knowledge sharing among organizations or organizational units accelerate individual and organizational learning. A firm's internal social networks enable faster information flow and sharing among employees, accelerating the diffusion of new knowledge or best practices across different departments and geographically separated offices (Molina et al., 2007; Szulanski, 1996). The information and knowledge being shared via social media is visible to different parties, reducing information asymmetry, avoiding knowledge duplication, and enabling management to make more 
informed decisions in a timely manner (Leonardi, 2014; Sanders, 2007). Social media also enable employees in different workplaces to work and collaborate virtually, overcoming geographic boundaries, reducing costs, and improving efficiency. For example, through an internal social media platform named connect.BASF, BASF enabled its 112,000 global employees across 88 business units to work and collaborate, increasing project efficiency by up to $25 \%$ (Kane et al., 2014). Wu (2013) showed that information workers in the knowledge-based society are especially valued for their ability to access pertinent information. Timely access to the information related to the tasks on hand directly improves the quality of work, while the ability to reach diverse information provided by distinct actors exposes new opportunities and resources.

Organizational knowledge is developed through interactions between organizations and their customers (Yli-Renko et al, 2001). Traditionally it is challenging for firms to gather information and knowledge from external customers, who are often physically dispersed. Although contemporary communications technologies such as email and instant messaging are able to overcome the geographical constraint, they usually enable information and knowledge exchange between a dyad or among a few group members, rather than across a firm's entire social networks (Leonardi, 2014). Social media provide a firm with an open and accessible resource that enables it to become closer to its customers. Customers can freely express their requirements and preferences regarding the firm's products and services. In fact, social media contain a wide range of perspectives from different reviewers and thus is considered as a superior choice to understand customer requirements ( $\mathrm{Li}$ et al., 2014), enabling the firm to improve quality management and enhance customer satisfaction.

Customer services and public relations management through social media also directly enhance service efficiency, reduce transaction costs, and improve firm image. For instance, by monitoring customer conversations on social networks closely, T-Mobile was able to identify at-risk customers and engage them specifically, which reduced customer attrition by $50 \%$ in only 90 days (Kane et al., 2014). Through social media, company information (e.g., new product information) can be distributed to and shared among customers in a timely manner, enhancing responsiveness and time-based efficiency (Eng and Quaia, 2009; Thomas and Akdere, 2013). For example, fast fashion retailer Zara 
leveraged Facebook, a popular social media platform, to gain customer feedback and increase customer responsiveness, perceived value, and commitment, thus enhancing customer satisfaction (Gamboa and Gonçalves, 2014). Positive experience shared by customers on social media can increase firms' reputation, decreasing sales and general administration costs (Chevalier and Mayzlin, 2006). In short, social media initiatives enable faster information flow and better knowledge sharing across firms' internal and external social networks, resulting in operational efficiency improvement.

\section{H1. Social media initiatives improve firms'operational efficiency.}

In addition to operational efficiency improvement, the social interaction facilitated by firms' social media initiatives is likely to stimulate new ideas and improve organizations' intellectual capacity. Social media technologies represent a paradigm shift that enable firms to secure faster information flow and better knowledge sharing across their internal and external social networks (Qualman, 2010; Treem and Leonardi, 2012). Social media facilitate external information flow, allowing firms to renew their knowledge and generate new ideas (Oettl and Agrawal, 2008). In particular, to simulate new ideas, firms must expose themselves to uncharted domains of information in evolving marketing and technological environments. Many social networking tools have sophisticated functions for searching and extending networks, allowing firms to access particular expertise and exposing them to different ideas (Piskorski, 2011; Wu, 2013).

According to social network theory, information-rich social networks that are low in cohesion and structural equivalence, but rich in structural holes are particularly helpful for organizational success (Burt, 2004). Structural holes created by social media enhance a firm's ability to access and gather information from non-redundant social groups (Wu, 2013). Subramaniam and Youndt (2005) noted that in Silicon Valley, frequent and informal personal contact between individuals is widely observed and commonly considered as a critical factor for fast technology developments. Levin and Cross (2004) revealed that scientists and researchers are much more likely to obtain useful information through dynamic interaction between people rather than impersonal sources such as a database or file cabinet. Lesser and Prusak (2000) reported that higher-performing faculty members have frequent interaction (though in shorter durations) in a wider range of non-typical office settings than do 
lower-performing faculty (Lesser and Prusak, 2000; Dahl and Pedersen, 2004; Becker, 2007). Product and service innovation requires a willingness to explore a wide range of new ideas from obscure and unrelated sources of information through different people and channels.

With fast-developing social media technologies, consumer networks, communities, and groups are increasingly seen as firms' strategic resources. Generating word-of-month through communication, consumers are regarded as active co-producers of products and services. Customer co-creation is defined as "an approach to innovation via which customers take an active part in designing new offerings" (Martini et al., 2014, p. 425). OM researchers traditionally regard customers as a strategic resource for quality improvement and innovativeness. Cassiman and Veugelers (2006) maintained that the knowledge acquired from external environments can complement internal R\&D activities for innovation purposes. Through social media, firms might proactively include customers in new product development (Cao et al., 2015). For instance, Starbucks' My Starbucks Idea and Dell's IdeaStorm social media platforms enable customers to participate in developing new products and submit innovative ideas to the firms directly (Bayus, 2013; Gallaugher and Ransbotham, 2010). Past studies have shown that customer involvement in new product development improves innovativeness (Koufteros et al., 2005).

The interaction facilitated by social media among employees from different geographic areas with different cultures may help generate creative ideas. Gassmann (2001) suggested that a project team with high cultural diversity "can lead to totally unexpected impulses of creativity and innovation" (p. 94). Employees from different departments such as R\&D, manufacturing, and marketing may view the same problems from different perspectives and their interaction via social media may help generate innovative solutions (Kahn, 2001). We develop the second hypothesis as follows:

\section{H2. Social media initiatives improve firms' innovativeness.}

Figure 1 provides the conceptual framework of this research.

$$
\text { --- Figure } 1 \text { about here --- }
$$

\section{Methods}

\subsection{Data collection}


We study the impact of firms' social media initiatives on their operational efficiency and innovativeness in this research. As a result, our sample was constrained by the availability of data on these two performance measures. We obtained the measures on operational efficiency and innovativeness from Compustat and Fortune databases, respectively (please refer to the next section for the details). We searched these two databases over the period from 2006 to 2012, and found that there were a total of 281 firms that had at least one piece of "consecutive two-year data" for both performance measures. We needed a minimum of one piece of consecutive two-year data for each observation because our Dynamic Panel Data (DPD) models (explained below) technically required one-year lagged performance measure for analysis (please refer to equations (5) and (6)). As mentioned above, we obtained the performance data from 2006 to 2012 (seven years), meaning that we had a maximum of six (and a minimum of one) pairs of consecutive two-year performance data for each sample firm. With 281 firms, the maximum number of firm-years available for analysis was 1,686 (i.e., 281 firms x 6 consecutive years). However, as mentioned above, not all the firms had the full six-year consecutive data in the two performance measures (but at least one set of consecutive data in both). We had both operational efficiency and innovativeness measures in 1,108 firm-years, operational efficiency measures only in 51 firm-years and innovativeness measures only in 17 firm-years. In 510 firm-years we had missing data on both measures and thus could not perform any analysis. We thus had 1,159 (i.e., 1,108 + 51) and 1,125 (i.e., 1,108 + 17) firm-years for the analysis of operational efficiency and innovativeness, respectively. These two figures (i.e., 1,159 and 1,125) were considered as effective firm-years for our subsequent analysis of the two performance measures.

As our dependent variables covered the period 2006 to 2012 and we also needed a one-year lag between the dependent and independent variables, we collected data related to social media initiatives covering the period 2006 to 2011 and obtained 841 announcements. There were 150 out of the 281 firms (53\%) that had at least one social media initiative over the six-year period 2006 to 2011, which is consistent with the finding of recent practitioner reports (e.g., Burson-Marsteller, 2011; Harvard Business Review Analytic Services, 2010).

However, not all these announcements were useful because some of these social media initiatives 
fell in the firm-years in which we had no performance data at all (i.e., the 510 firm-years). We had 730 and 690 usable announcements of social media initiatives in these 1,159 and 1,125 effective firm-years. The average numbers of announcements per firm per year were 0.629 and 0.613 for the analysis of operational efficiency and innovativeness, respectively. The ranges were from 0 to 30 . We had at least one announcement in $320(27.61 \%)$ and $310(27.55 \%)$ firm-years out of these 1,159 and 1,125 effective firm-years, respectively. Table 2 provides a summary. Note that the 1,159 and 1,125 firm-years (in 281 firms) are considered as effective observations (and unit of analysis), whether or not they have social media initiatives. Our DPD models, in the simplest sense, is to longitudinally study the relative yearly performance changes for firms at various levels of social media initiatives, including firms with no initiatives at all. Note that the actual analysis is based on the relative numbers of social media initiatives in different industries (i.e., industry standardized scores instead of the actual number from 0 to 30). It is a longitudinal analysis of relative performance changes, comparing within firms across different years and in the same year across different firms.

--- Table 2 about here ---

These 281 firms represent 37 different industries based on the 2-digit SIC codes. The top 20 industries of our sample firms are presented in Panel A of Table 3. It shows that the sample contains firms from a very wide range of industries in both the manufacturing and service sectors. The top five sectors based on 2-digit SIC codes are 1) electronics \& other electric equipment, 2) business services, 3) chemical \& allied products, 4) chemical \& allied products manufacturing, and 5) transportation equipment, representing $41.9 \%$ of the total sample. Interestingly, four out of the top five sectors are in the manufacturing industries. We also show the characteristics of the sample firms in terms of sales, total assets, operating income, number of employees, cost of goods sold, capital expenditure, return on assets, age, R\&D expense, and advertising expense in Panel B of Table 3.

--- Table 3 about here ---

\subsection{Measurements}

Operational Efficiency. We measured firms' operational efficiency based on the Stochastic Frontier Estimation (SFE) methodology (Dutta et al., 2005; Li et al., 2010). Compared with conventional 
efficiency measures using a single financial indictor such as labor productivity and inventory turnover, SFE provides a more comprehensive measure of a firm's overall operational efficiency. The SFE approach models a firm's efficiency in transforming various operational resources (e.g., number of employees, cost of goods sold, capital expenditure etc) into operational output (Li et al., 2010) and is better able to capture the idea of operational efficiency defined from the traditional OM perspective (i.e., relative efficiency in transforming input to output). While the conventional efficiency measures are criticized for their inability to account for industry heterogeneity (Eroglu and Hofer, 2011), SFE indeed measures a firm's relative efficiency in its industry (Dutta et al., 2005), thus making the results comparable across industries. In addition, SFE explicitly incorporates the random error term into its estimation, so it can more accurately capture the efficiency variations beyond that caused by random shocks (Vandaie and Zaheer, 2014).

To implement SFE, we first constructed a stochastic production function to model the relationship between a firm's operational resources (i.e., number of employees, cost of goods sold, and capital expenditure) and its operational output (i.e., operating income) as follows:

$$
\begin{aligned}
\ln (\text { Operating Income })_{i j t} & =\beta_{0}+\beta_{1} \ln (\text { Number of Employees })_{i j t} \\
& +\beta_{2} \ln (\text { Cost of Goods Sold })_{i j t} \\
& +\beta_{3} \ln (\text { Capital Expenditure })_{i j t}+\varepsilon_{i j t}-\eta_{i j t},
\end{aligned}
$$

where $\varepsilon_{i j t}$ is the stochastic random error term and $\eta_{i j t}$ represents the technical inefficiency of firm $i$ in industry $j$ (2-digit SIC codes) in year $t . \eta_{i j t}$ ranges from 0 to 1 , with 0 indicating no technical inefficiency (i.e., the frontier at which the firm is technically efficient). Therefore, $\eta_{i j t}$ is a relative measure of how inefficient a firm is when compared with the corresponding frontier in the same industry within the same year. Therefore, we calculated the operational efficiency of firm $i$ in industry $j$ in year $t$ as follows:

Operational Efficiency ijt $_{1}=1-\widehat{\eta_{\imath \jmath t}}$.

Innovativeness. We relied on the innovation ratings published by Fortune annually to measure firms' innovativeness. Innovation rating is one of nine criteria used by Fortune to pick the Most Admired Companies (MAC) from the Fortune 1,000 companies annually. This rating has been widely used in 
prior studies (e.g., Cho and Pucik, 2005; Cui and O'Connor, 2012; Staw and Epstein, 2000) as a measure of innovativeness at the firm level. For instance, using the innovation ratings from Fortune, Cui and O'Connor (2012) investigated how firms' alliance portfolios affect their innovation performance, while Staw and Epstein (2000) studied whether popular management techniques make firms more innovative. The reliability and validity of this measure have been verified by Cho and Pucik (2004). Consistent with our measurement of operational efficiency, we are interested in the relative innovativeness of a firm compared with its industry peers in order to account for any inter-industry differences. Therefore, we standardized the innovation rating of a firm within its industry as defined by Fortune. Moreover, in view of the one-year lag between the survey and publication of the innovation ratings, we computed the innovativeness of firm $i$ in industry $j$ in year $t$ as follows:

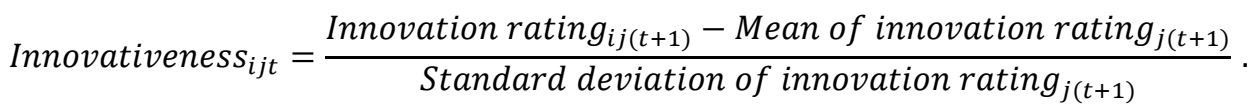

Social Media Initiatives. We searched for the announcements of social media initiatives in Factiva and counted the numbers to quantify firms' social media efforts. We chose Factiva instead of other possible sources for several reasons. First, Factiva contains news articles from top media outlets such as The Wall Street Journal, The New York Times, as well as hundreds of other sources (Gnyawali et al., 2010). Factiva thus is more likely to cover firms' announcements of social media initiatives than any single media source. Second, although it is possible to collect data about firms' social media initiatives directly from public social media platforms such as Facebook and Twitter, some social media initiatives are deployed on private or internal social media platforms that are not publicly accessible (e.g., Bills, 2007). Factiva, on the other hand, covers the announcements of social media initiatives deployed on both public and private social media platforms, thus using Factiva avoids the possible bias arising from focusing on public social media platforms only.

Collecting data from Factiva was a labor-intensive task due to the huge amount of information it contains. We recruited 12 student assistants to carry out this task. To ensure quality and consistency across different student assistants, we developed a standard data collection procedure for them to 
follow. We also ensured their understanding by conducting a test on them. The student assistants needed to demonstrate they were able to identify the same set of announcements for particular firms in the test. We provided additional training in case of inconsistency. All the samples obtained were further verified by our research team.

We followed prior studies in collecting announcements from Factiva (e.g., Dehning et al., 2007; Zhang and Xia, 2013). First, we searched news articles in Factiva with a combination of our sample firms' names and some general social media terms such as social media, social network, social software, and Web 2.0. We limited our searches to the six-year period 2006 to 2011. For all the news articles obtained from Factiva, we then read through the text to identify the social media initiatives of our sample firms. We thus excluded announcements concerning the social media initiatives of other firms or non-social media initiatives (e.g., senior executive appointments, mergers and acquisitions related to social media) of our sample firms. We also dropped repeated reports of the same social media initiative by different publication sources to avoid double counting. As an example, we show in the Appendix a news article extracted from Factiva reporting the social media initiative of one of our sample firms, Honeywell, to enable employees to locate, manage, and share information and knowledge.

In line with our measurements of operational efficiency and innovativeness, we standardized the social media initiatives of a firm within its industry (2-digit SIC codes) to account for any inter-industry differences as follows:

Social Media Initiatives ${ }_{i j t}$

$=\frac{\text { Number of social media initiatives }_{i j t}-\text { Mean of number of social media } \text { initiatives }_{j t}}{\text { Standard deviation of number of social media } \text { initiatives }_{j t}}$,

where $i, j$, and $t$ are firm, industry, and year indices, respectively.

Control Variables. We included five control variables, namely firm size, firm profitability, firm age, firm R\&D intensity, and firm advertising expense in our research as they may be related to firms' operational efficiency and innovativeness (Bellamy et al., 2014; Cohen and Levinthal, 1990; Kortmann et al., 2014; Kwong and Norton, 2007; Wu et al., 2010). We measured firm size as the 
natural logarithm of a firm's sales (Bardhan et al., 2013, Hendricks et al., 2009), firm profitability as a firm's return on assets (Chizema et al., 2015; Mukherji et al., 2011), firm age as the natural logarithm of the number of years since a firm's founding (Bellamy et al., 2014; Vandaie and Zaheer, 2014), firm R\&D intensity as a firm's R\&D expenditures over sales (Ba et al., 2013; Bardhan et al., 2013), and firm advertising expense as the natural logarithm of a firm's spending on advertising (Lou, 2014; Pirinsky and Wang, 2006). We also included year (2006-2011) and industry (two-digit SIC codes) dummies in our research to control for any unobservable time- and industry-specific effects.

\subsection{Sample verifications}

A major concern about our measure based on firms' announcements is whether firms actually implement the social media initiatives they have announced in Factiva. To address this concern, we randomly selected 15\% (110) of the 730 announcements we collected from Factiva. We read through each of these 110 announcements to identify the social media platforms deployed by firms. We found that among these 110 announcements, 88 involved publicly accessible social media platforms such as Facebook, Twitter, and firms' own websites (e.g., Dell's IdeaStorm). For these 88 announcements, we were able to access the corresponding social media platforms directly or via Internet Archive's Wayback Machine (http://archive.org/web/web.php), thus confirming their actual implementation. However, for the remaining 22 announcements that involved internal or private social media platforms, we could not access these platforms directly to verify their implementation. Nevertheless, we were able to verify 19 of these 22 announcements based on third-party sources such as books, magazines, and reports. For instance, although we could not access the Bank of New York Mellon's internal social media platform that was designed for employee collaboration (Bills, 2007), a case study conducted by Carter (2012, p. 112) confirmed the deployment of this internal platform. Overall, we were able to verify 107 (97.3\%) of the 110 randomly-selected announcements, thus showing the consistency between the announcements and implementation of firms' social media initiatives.

To further verify our measurement of social media initiatives based on announcements from Factiva, we obtained the total impressions served across social media of 30 firms from January to August 2012 provided by comScore. An impression is an actual count of responses in billions from a 
web server to user browser in social media. comScore's measure is regarded as "the best proxy for overall economic activity" of a firm on social media (Edwards, 2012). We measured the social media initiatives of these 30 firms over the same period (i.e., January to August 2012) based on our searches in Factiva. We then compared our measure with that of comScore. The significant correlation between the two measures $(b=0.45, p<0.05)$ provides support for our approach to measuring firms' social media initiatives based on announcements from Factiva.

\subsection{Dynamic panel data (DPD) models}

We constructed two dynamic panel data (DPD) models to test our hypotheses as follows:

Operational Efficiency ${ }_{i(t+1)}$

$=\alpha_{0}+\alpha_{1}$ Operational Efficiency $_{i t}+\alpha_{2}$ Social Media Initiatives $_{i t}+\alpha_{3}$ Firm Size $_{i t}$

$+\alpha_{4}$ Firm Profitability $_{i t}+\alpha_{5}$ Firm Age $_{i t}+\alpha_{6}$ Firm R\&D Intensity $_{i t}$

$+\alpha_{7}$ Firm Advertising Expense Et $_{i t}+\varepsilon_{i t}$.

Innovativeness $_{i(t+1)}$

$=\beta_{0}+\beta_{1}$ Innovativeness $_{i t}+\beta_{2}$ Social Media Initiatives $_{i t}+\beta_{3}$ Firm Size $_{i t}$

$+\beta_{4}$ Firm Profitability $_{i t}+\beta_{5}$ Firm Age $_{i t}+\beta_{6}$ Firm R\&D Intensity $_{i t}$

$+\beta_{7}$ Firm Advertising Expense $e_{i t}+\varepsilon_{i t}$.

We included lagged dependent variables as regressors in the two models because firm performance such as operational efficiency and innovativeness could be path dependent and persistent over time (Mukherji et al., 2011; Vandaie and Zaheer, 2014). The inclusion of lagged dependent variables made our models "dynamic" in nature, versus traditional "static" panel data models without considering the persistent influence of past performance. Consistent with prior DPD studies (e.g., Mukherji et al., 2011; Vandaie and Zaheer, 2014), we included a one-year lag of the dependent variables as a regressor in the two models ${ }^{1}$. We also maintained a one-year lag between the dependent and hypothesized variables. Finally, we included all the five control variables, namely firm size, firm profitability, firm age, firm R\&D intensity, and firm advertising expense in the two models.

\footnotetext{
${ }^{1}$ Our results remained consistent when a two-year lag of the dependent variables was included.
} 


\subsection{System generalized method of moments (GMM) estimation}

Our research context gives rise to several challenges for testing our proposed hypotheses. First, although we included lagged dependent variables in the models to account for the persistent influence of past performance, the lagged dependent variables are correlated with the fixed effects in the error term (i.e., $\varepsilon_{i t}$ ) by construction, leading to dynamic panel bias. While Kiviet (1995) suggested that the least squares dummy variables (LSDV) estimator is able to handle the dynamic panel bias, it works only for balanced panels (Roodman, 2009) and is unsuitable for our unbalanced sample with some firms having more observations than the others. Moreover, although we maintained a one-year lag between the dependent and hypothesized variables in the two models, we could not completely rule out the possibility of endogeneity. In particular, it is possible that firms' strategies and performance co-determine each other (Bardhan et al., 2013; Wintoki et al., 2012). On the one hand, firms' strategies such as pursuing social media initiatives may affect firms' performance such as operational efficiency and innovativeness as we have elaborated above. On the other hand, firms' operational efficiency and innovativeness may also affect firms' decisions to adopt social media, leading to the possibility of two-way causality. Therefore, without taking this possible reverse causation into account, the impact of social media initiatives on operational efficiency and innovativeness could be overstated. Another potential source of endogeneity is the unobservable firm-specific heterogeneity (Wintoki et al., 2012). In other words, some unobservable factors such as managerial ability and corporate culture may affect firms' use of social media and organizational consequences such as operational efficiency and innovativeness simultaneously, making the relationships between social media initiatives and these organizational outcomes biased. Mathematically, the endogeneity concern implies that the independent variables in equations (5) and (6) are correlated with the corresponding error term (i.e., $\varepsilon_{i t}$ ). Although the conventional instrumental variables (IV) techniques that use external variables as instruments can address the endogeneity concern, it is difficult to obtain such strictly exogenous instruments externally as pointed out by prior studies (see e.g., Bardhan et al., 2013; Wintoki et al., 2012).

Considering the challenges discussed above, we followed recent DPD studies (e.g., Bardhan et al., 
2013; Chizema et al., 2015; Wintoki et al., 2012) by employing generalized method of moments (GMM) estimation to test our hypotheses. Specifically, we adopted the System GMM estimator developed by Arellano and Bover (1995) and Blundell and Bond (1998) in this research. The System GMM estimator offers several important advantages for our research. First, the System GMM estimator addresses the dynamic panel bias directly by instrumenting the lagged dependent variables with variables uncorrelated with the fixed effects in the error term (Roodman, 2009). Moreover, the System GMM estimator is suitable for our data with unbalanced panels. An extensive comparison of different DPD techniques conducted by Flannery and Hankins (2013) suggests that the System GMM estimator appears to be one of "the most robust methodologies for unbalanced panels with endogenous variables" (p. 13). Finally, although the System GMM estimator also employs the IV techniques to deal with the endogeneity issue, it does not rely on external variables that are outside the immediate dataset to construct instruments. Instead, the System GMM estimator constructs instruments internally with the transformation of existing variables, overcoming the difficulty in obtaining exogenous instruments externally (Roodman, 2009; Wintoki et al., 2012).

To implement the System GMM estimator, we first transformed the DPD models expressed in equations (5) and (6) into their first difference forms as follows:

$\triangle$ Operational Efficiency $y_{(t+1)}$

$=\alpha_{1} \Delta$ Operational Efficiency it $_{i}+\alpha_{2} \Delta$ Social Media Initiatives $_{i t}+\alpha_{3} \Delta$ Firm Size $_{i t}$

$+\alpha_{4} \Delta$ Firm Profitability $_{i t}+\alpha_{5} \Delta$ Firm Age $_{i t}+\alpha_{6} \Delta$ Firm R\&D Intensity $_{i t}$

$+\alpha_{7} \Delta$ Firm Advertising Expense Eit $_{i t}+\Delta \varepsilon_{i t}$.

$\Delta$ Innovativeness $_{i(t+1)}$

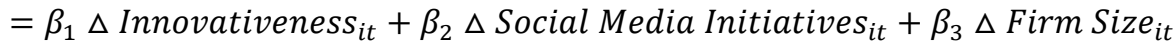

$+\beta_{4} \Delta$ Firm Profitability $_{i t}+\beta_{5} \Delta$ Firm Age $_{i t}+\beta_{6} \Delta$ Firm R\&D Intensity $_{i t}$

$+\beta_{7} \Delta$ Firm Advertising Expense $e_{i t}+\Delta \varepsilon_{i t}$.

For each variable $\mathrm{X}$ in equations (7) and (8), $\Delta X_{i(t+1)}$ represents $X_{i(t+1)}-X_{i t}$ and $\Delta X_{i t}$ represents $X_{i t}-X_{i(t-1)}$. The transformation process removes the time-invariant fixed effects in the 
error term (i.e., the unobservable firm-specific heterogeneity) in the original equations (5) and (6). Moreover, instead of using exogenous instruments outside the immediate dataset, Arellano and Bond (1991) proposed a GMM estimator that uses the lagged values of the endogenous regressors as instruments for the variables in the difference equations (i.e., equations (7) and (8)), which is commonly known as the Difference GMM estimator (Bapna et al., 2013). Valid instruments, by definition, should be highly correlated with the variables to be instrumented but orthogonal to the error term in order to address the endogeneity concern (Chizema et al., 2015). These requirements result in a set of "moment conditions" that enables the Difference GMM estimator to select the suitable lagged values as valid instruments for the difference equations. Although the Difference GMM estimator has been widely adopted in prior DPD studies (e.g., Dezsö et al., 2012; Sodero et al., 2013), Blundell and Bond (1998) showed that the instruments used in the Difference GMM estimator could be weak if the autoregressive process becomes too persistent over time, as is possible in our study involving firm performance.

To address this weak instruments concern, Arellano and Bover (1995), and Blundell and Bond (1998) developed a new GMM estimator with additional moment conditions in which the lagged differences of the endogenous regressors are used as instruments for the original-level equations. This new GMM estimator is usually referred to as the System GMM estimator (Bapna et al., 2013; Bardhan et al., 2013) as it estimates a system of two equations simultaneously, i.e., the original-level equation and the transformed difference equation. However, as the fixed effects are still present in the error term of the original-level equations, an additional assumption is required in order to implement the System GMM estimator. Nevertheless, although the endogenous variables are correlated with the fixed effects in the error term by construction, it is assumed that the correlation is constant over time (i.e., time-invariant) (Arellano and Bover, 1995; Blundell and Bond, 1998). This is a reasonable assumption for the data over a relatively short time period such as ours with a maximum of six years from 2006 to 2011 (Wintoki et al., 2012). This assumption allows the System GMM estimator to develop differences as instruments to make them exogenous to the fixed effects in the error term and address the endogeneity concern (Roodman, 2009). Therefore, the System GMM estimator uses 
lagged differences as instruments for the original-level equations, in addition to the use of lagged levels as instruments for the transformed difference equations. The introduction of more instruments enables the System GMM estimator to address the concern of weak instruments in the Difference GMM estimator and improve the estimation efficiency dramatically (Roodman, 2009). We implemented the two-step System GMM estimator in our research as it is efficient and robust to any pattern of heteroskedasticity (Roodman, 2009).

\section{Results}

Table 4 reports the correlations among all the variables included in this research. The results show that each of the two dependent variables is highly correlated with their lagged values $(b=0.799$ for operational efficiency and $b=0.798$ for innovativeness), providing support for controlling the lagged dependent variables in the regression models. Tables 5 and 6 report the test results on the impacts of social media initiatives on operational efficiency and innovativeness, respectively. For all the models shown in Tables 5 and 6, the lagged dependent variables are positive and significant $(p<0.05)$, providing strong support for the persistent influence of past performance in terms of operational efficiency and innovativeness.

\section{--- Table 4 about here --- \\ --- Table 5 about here --- \\ --- Table 6 about here ---}

We conducted two tests to verify the suitability of applying the System GMM estimator in our research. The first one is the Sargan test, which is used to check the orthogonality of the instrumental variables to the error term (Chizema et al., 2015). The Sargan statistic is not significant $(p>0.05)^{2}$ in both Tables 5 and 6, failing to reject the null hypothesis that the specific instrumental variables are uncorrelated with the error term. Therefore, the instruments used in this research could be viewed as exogenous and appropriate. The second test is to check the autocorrelation in the idiosyncratic

\footnotetext{
${ }^{2}$ A more conservative threshold of $p$-value suggested by Roodman (2009) is 0.25 and he also warned that this $p$-value should not be too close to 1 . The $p$-values of our Sargan statistic in Tables 5 and 6 are higher than 0.25 and lower than 0.5 , satisfying Roodman's (2009) conservative requirements.
} 
disturbances (those apart from the fixed effects). As this test is applied to the residuals in differences, the first-order autocorrelation (AR1) should be significant by construction ${ }^{3}$, as shown in Tables 5 and $6(p<0.05)$. Therefore, we needed to rely on the second-order autocorrelation in differences (AR2) to determine the first-order autocorrelation in levels (Roodman, 2009). The statistically insignificant AR2 $(p>0.05)$ in Tables 5 and 6 suggests that we fail to reject the null hypothesis that there is no serial correlation in the idiosyncratic disturbances. As a result, there is no evidence that our System GMM models are misspecified.

In addition to the results based on the System GMM estimation, we also include the OLS results in the two tables for comparison. Both the System GMM and OLS models in the two tables are significant $(p<0.05)$ based on the Wald Chi-square and $F$ statistics, respectively. However, the coefficients and significance levels of the lagged dependent variables are much higher in the OLS models than in the System GMM models. This may be due to the inability of the OLS estimator to handle the high correlations between the lagged dependent variables and the fixed effects in the error term. Such an upward-biased estimation for the lagged dependent variables in the OLS models is consistent with the findings of prior DPD studies (e.g., Bapna et al., 2013; Flannery and Hankins, 2013; Roodman, 2009).

Two control variables, namely firm profitability and firm size, remain positively significant $(p<$ 0.05 ) in all the models in Tables 5 and 6, respectively, suggesting that while more profitable firms appear to be more efficient, larger firms seem to be more innovative. The coefficients of social media initiatives are also positive and significant $(p<0.05)$ across all the models in Tables 5 and 6 . The results show that social media initiatives improve firms' operational efficiency and innovativeness, thus supporting $\mathrm{H} 1$ and $\mathrm{H} 2$.

We further employed an alternative matching method and the difference-in-difference approach to check the robustness of our findings regarding the effects of social media initiatives on operational efficiency and innovativeness. Specifically, we first matched firms that adopt social media in year $t$

\footnotetext{
${ }^{3}$ Let $v_{i t}$ be the idiosyncratic disturbance term. $\Delta v_{i t}$ (i.e., $v_{i t}-v_{i(t-1)}$ ) should be correlated with $\Delta v_{i(t-1)}$ (i.e., $\left.v_{i(t-1)}-v_{i(t-2)}\right)$ via the shared $v_{i(t-1)}$ term.
} 
with their industry peers (2-digit SIC codes) that do not adopt social media. We then computed the changes in performance (i.e., operational efficiency and innovativeness) from year $t$ to year $t+1$ for both social media adopters and their matched non-social media adopters. Finally, we calculated the difference-in-difference as the differences in changes between the social media adopters and the matched non-social media adopters. Table 7 reports the difference-in-difference results, which are positive and statistically significant for both operational efficiency $(b=0.005, p<0.05)$ and innovativeness $(b=0.120, p<0.01)$. The results thus suggest that social media adoption helps firms improve operational efficiency and innovativeness, consistent with our System GMM and OLS results.

--- Table 7 about here ---

\section{Discussions and conclusion}

Organizations across the globe are increasingly adopting social media for customer relationships management, employee collaboration, and business intelligence (Bharati et al., 2015). Although social media have fundamentally changed the way in which people "communicate, collaborate, consume and create" (Aral et al., 2013, p. 3), the real impact of social media initiatives by firms has remained largely unexplored, particularly from the OM perspective. Social media initiatives facilitate information flow and knowledge sharing within and across organizations, which in turn improves firms' effectiveness and innovativeness in a dynamic, knowledge-based business environment. By keeping in touch with distinctive members in different parts of the world within and outside the organization, employees can access knowledge residing in different experts. In fact, previous research showed that social media adoption supports the idea of knowledge management by allowing unrestricted sharing of knowledge, information, and data among various stakeholders (Alberghini et al., 2014). Using secondary data in a longitudinal setting, we showed that social media can be strategically deployed by firms to improve organizational performance.

Social media represent "one of the most transformative impacts of information technology on business, both within and outside the firm boundaries" (Aral et al., 2013, p. 3). Through social media, companies can improve and transform their processes in virtually every organizational function, from 
public relationships to marketing, and to internal operations and product innovations (Luo et al., 2013). As shown in Table 1, organizations adopt social media for a wide-range of organizational purposes, including sales and promotion, customer services, internal and external collaboration, and open innovation and idea sourcing. Yet, burgeoning research in this area is predominately directed to marketing and consumer online behaviors at the individual level, rather than considering social media initiatives aggregately at the firm level. Our research takes a strategic OM perspective, exploring the possibility that informal, relationship-oriented online systems like social media can be tactically deployed by firms to produce positive effects on productivity and innovativeness.

Traditional OM research focuses on the transactional benefits of information technology, showing how information technology improves scheduling and coordination, and reduces time between placing orders and delivery. The traditional perspective of information technology adoption emphasizes seamless integration of data flow (e.g., Rabinovich et al., 2003), particularly in the supply chain context. More recently, OM researchers have also stressed the importance of building trust and relationships through the adoption of e-business technologies, reducing both operational risks and transaction costs (Johnson et al., 2007). Our research departs from this stream of research in that we do not consider information technology simply as a tool for improving process integration and transactional efficiency. Compared with other organizational information systems (e.g., ERP) and e-business (e.g., CPFR), the information flow through social media is often informal, unstructured, and less organized. In fact, social media were originally developed not for organizational purposes. Instead, it is for connecting people, interpersonal communication, and maintaining relationships. Unlike e-business technologies, seamless data flow and process automation is unlikely to be the primary benefit for firms' social media initiatives. In contrast, social media strengthen social communication, increase information diversity, and supplement knowledge flow through traditional organizational structures (Aral et al., 2013). Facilitating business transformation in terms of managing customer relationships, business processes, and product innovations, social media are likely to have a wider range of organizations functions and implications that are different from the traditional e-business technologies (e.g., CRFR, ERP, POS, ... etc). 


\subsection{Theoretical and managerial implications}

Taking the resource-based view of a firm's information capability in this research, we consider firms' social media initiatives as strategic resources for capacity improvement. In line with the recent discussion regarding the adoption of RBV in the OM context (Hitt et al., 2016b), we focus on the mid-level organizational outcomes of operational efficiency and innovativeness. Hitt et al. (2016a) maintained that RBV has the potential of greater integration with the knowledge-based view and the theoretical lens of dynamic capability. In addition to process integration through the traditional e-business technologies, firms can also create a competitive edge through fluid information flow, sustaining their knowledge-based advantage. Although OM researchers have long realized the competitive advantages residing in distinct routines and capabilities, they rarely consider enhancing such capabilities by building social information networks and facilitating information brokerage through social media technologies. The contemporary research on RBV suggests that although process routines and operational advantage are critical capabilities to firms, they can be quickly eroded. A higher level of capability through knowledge-based advantage and dynamic capacity is likely to be more enduring. Compared with previous OM research, we consider information technology adoption at the more strategic level for reaching untapped knowledge sources, rather than just transactional effectiveness.

We argue that firms' social media initiatives lead to operational efficiency and innovativeness through an information-rich social network that yields knowledge-based advantage. Specifically, social media networks that are low in repeated connections (i.e., low in cohesion) but high in connectivity to uncharted domains (i.e., rich in structural holes) are particularly beneficial for firms. Wu (2013) theorized and empirically demonstrated that information diversity and social communication are the "two intermediate mechanisms" (p. 30) of an information-rich social network through which social media improve employees' productivity. According to Aral and Van Alstyne (2011), information in local, closely connected network neighborhoods tends to be redundant, providing mainly repetitive information. Instead, structurally diversified contacts should provide channels through which new information flows (Burt, 1992). The access to novel information through 
social media should increase the breadth of employees' absorptive capacity, simulating learning and new ideas (Cohen and Levinthal, 1990; Rodan and Galunic, 2004). In addition, with the rapid globalization of business, workforces become increasingly diversified (Bente et al., 2008; Crouse et al., 2011). Social media are increasingly more important not only for information sharing and idea generation, but for continuous task update, employee collaboration, and customer co-creation across geographical areas (Bente et al., 2008; Crouse et al., 2011).

Our research offers some important practical implications for managers. We provide practitioners with initial empirical evidence that social media initiatives help enhance efficiency and foster innovativeness of firms. For practitioners, in addition to public relations and marketing communication, investments in social media initiatives also help facilitate employee collaboration, interfirm coordination, and idea generations. More practically, managers can consider adopting internal online knowledge sharing networks, establishing business-to-business online networking communities of their specific industry, enhancing customer interaction through publishing blogs and product ratings, and initiating online idea sourcing by posting and rating ideas. Certainly, operations managers need to think strategically how unrestricted information flow can be valuable to their firms, in particular how social media can be adopted to reach untapped knowledge sources. For OM practitioners, the idea of efficiency is not simply to streamline operations and reduce complexity, but to develop an information-rich social network that yields knowledge-based advantage.

The need for organizations to be both efficient and innovative (i.e., the concept of ambidexterity) has been an increasing concern for operations managers. Traditionally, many OM techniques emphasize instilling best practices and optimizing business processes. Such OM practices might be in conflict with organizational innovation. For example, Benner and Tushman (2003) argued that process techniques, by design and intent, exploit existing capabilities with a scant concern for innovation capability building. Process management techniques such as ISO 9000 are geared towards reducing variations and achieving greater conformance, enhancing operational efficiency at the expense of exploratory innovation (Benner and Tushman, 2002). Some process management practices are blamed for having "destroyed more innovation than any other" (Amabile and Khaire, 2008, p. 104). Our 
research, in contrast, indicates that through promoting information flow, a firm's social media initiatives contribute to both operational efficiency and innovation improvements. Consistent with recent OM research (e.g., Choo et al., 2007; Kim et al., 2012; Schroeder et al., 2008), we stress the need for both efficiency and innovation (i.e., exploitative and exploratory learning). We believe that OM principles and techniques will also benefit from a continuous stream of knowledge exchange facilitated by contemporary information technology such as social media. Exploitative and exploratory learning are two critical elements for the long-term prosperity of organizations. Current OM research stresses the importance of rigorous process management, organizational conformance, and variance reduction, while simultaneously "creating a context that enables problem exploration between disparate organizational members" (Schroeder et al., 2008, p. 536), leading to greater and more heterogeneous knowledge. This is in line with the recent perspective that the OM function is an organizational learning and exploration process, which in turn will benefit from information flow in a knowledge-based environment (e.g., Gutiérrez Gutiérrez et al., 2012; Jacobs et al., 2015).

\subsection{Limitations and concluding remarks}

Our research is limited in terms of its scope. Most notably, we demonstrate that firms' social media initiatives enhance operational efficiency and innovativeness in general. However, we do not consider the circumstances under which firms are likely to benefit more from social media. Certainly, we believe that some firms are likely to benefit from social media more than others. Wu (2013) argued that knowledge-based, information-intensive jobs (e.g., business consultants or head hunters) are likely to benefit more from social media adoption. On the other hand, highly focused organizations (e.g., OEM factories) may not benefit much from social media initiatives. Another related question concerns whether there exists an optimal level of socialization and information flow within an organization (or for an employee). Obviously, information processing and socializing can be time-consuming and the adoption of social media within firms can distract work-related duties. There exists a trade-off between exploring uncharted domains and a focus on current tasks based on existing knowledge.

We acknowledge that our measure of social media initiatives based on related firms' 
announcements in Factiva is not perfect. An alternative measurement approach is to use data about firms' annual budgets or spending on social media. However, we have tried various ways, including consulting directly with International Data Corporation, a research firm specializing in information technology and consumer technology, but failed to obtain the social media spending data at the firm level. Nevertheless, social media announcements from Factiva actually provide quite detailed descriptions of a firm's social media initiatives, providing a good proxy of the actual adoption of a firm. Moreover, our verification of firms' implementation of social media initiatives and data from comScore provide further support to our measurement approach.

The strict proof of the cause and effect relationship between independent and dependent variables is always a challenge in management research. Our research, like any OM research, might suffer from the issue of endogeneity. As pointed out by Hitt et al. (2016b), the best way to avoid the endogeneity and common method bias is in the initial research design. In this research we used panel data with time lags between dependent and independent variables. Through the analysis of six-year longitudinal panel data, we actually examined the yearly performance effects (operational efficiency and innovativeness) of social media initiatives. We compared the yearly differences between firms with social media initiatives (at different levels) with organizations without any social media initiatives. Despite this, the issue of endogeneity remains because the choice of firms to adopt social media initiatives is not random. To tackle this problem, we used System GMM estimation in our analysis. System GMM estimation employs the IV techniques to construct instruments that are correlated with the endogenous variables but orthogonal to the error term. More importantly, the System GMM estimator overcomes the difficulty in obtaining external exogenous instruments through transforming existing time-series data, and addresses the weak instruments concern with a simultaneous estimation of both level and difference equations.

To conclude, we empirically demonstrated that social media initiatives have positive impacts on operational efficiency and innovativeness, two critical organizational objectives of firms. By collecting longitudinal data from multiple sources, we constructed two DPD models to account for the influence of firms' past operational efficiency and innovativeness, respectively, and employed the 
System GMM estimator to address the endogeneity concern. We ground our research in the resource-based view of the firm and social network theory with regard to information flow. Social media have revolutionized the way in which an organization is related to customers, other stakeholders, and the public, tapping different possibilities in various organizational functions, from marketing to operations management and new product development.

We believe that more research on the impact of firms' social media initiatives is needed. We encourage OM researchers to examine other possible operational outcomes of firms' social media efforts at both internal operational and supply chain levels. At the internal operational level, anecdotal evidence suggests that adopting social media in organizations might lead to higher product quality, customer satisfaction, and operational visibility (Kane et al., 2014; Kiron et al., 2013; Martin and van Bavel, 2013). At the supply chain level, academics can focus on performance outcomes such as buyer-supplier relationship, inter-firm trust, and supply chain efficiency (e.g., inventory days). While we focus on the positive performance outcomes of social media, we should not lose sight of their possible underlying drawbacks. For example, some practitioners have warned that excessive information flow through social media may lead to employee burnout and unrestrained knowledge sharing to external social networks may hurt firms' competitive advantage (Gaudin, 2010; Molok et al., 2010). Most importantly, we believe that researchers should move beyond the simple question as to whether or not firms' social media initiatives lead to positive performance outcomes. Instead, researchers should study the impacts of contingency factors and their performance implications. As discussed, firms' benefits from social media initiatives might be contingent on their operational characteristics such as information intensity, knowledge requirements, and supply chain complexity. For example, firms with responsive versus efficient supply chain strategies might benefit differently from their social media initiatives.

\section{Acknowledgment}

We thank an Associate Editor and two anonymous referees for their many helpful comments on earlier versions of our paper. This paper was partially supported by the Research Grants Council of Hong Kong under grant number PolyU 5493/13H. 


\section{References}

Alberghini, E., Cricelli, L., Grimaldi, M., 2014. A methodology to manage and monitor social media inside a company: A case study. Journal of Knowledge Management 18 (2), 255-277.

Amabile, T.M., Khaire, M., 2008. Your organization could use a bigger dose of creativity. Harvard Business Review 86, 101-109.

Aral, S., Brynjolfsson, E., Van Alstyne, M., 2012. Information, technology, and information worker productivity. Information Systems Research 23 (3), 849-867.

Aral, S., Dellarocas, C., Godes, D., 2013. Introduction to the special issue - Social media and business transformation: A framework for research. Information Systems Research 24 (1), 3-13.

Aral, S., Van Alstyne, M., 2011. The diversity-bandwidth trade-off. American Journal of Sociology 117 (1), 90-171.

Arellano, M., Bond, S., 1991. Some tests of specification for panel data: Monte Carlo evidence and an application to employment equations. The Review of Economic Studies 58 (2), 277-297.

Arellano, M., Bover, O., 1995. Another look at the instrumental variable estimation of error-components models. Journal of Econometrics 68 (1), 29-51.

Ba, S., Lisic, L. L., Liu, Q., Stallaert, J., 2013. Stock market reaction to green vehicle innovation. Production and Operations Management 22 (4), 976-990.

Bapna, R., Langer, N., Mehra, A., Gopal, R., Gupta, A., 2013. Human capital investments and employee performance: An analysis of IT services industry. Management Science 59 (3), 641-658.

Bardhan, I., Krishnan, V., Lin, S., 2013. Business value of information technology: Testing the interaction effect of IT and R\&D on Tobin's Q. Information Systems Research 24 (4), $1147-1161$.

Barney, J., 1991. Firm resources and sustained competitive advantage. Journal of Management 17 (1), 99-120.

Bayus, B.L., 2013. Crowdsourcing new product ideas over time: An analysis of the Dell IdeaStorm community. Management Science 59 (1), 226-244. 
Becker, F., 2007. Organizational ecology and knowledge networks. California Management Review 49 (2), 42-61.

Bellamy, M.A., Ghosh, S., Hora, M., 2014. The influence of supply network structure on firm innovation. Journal of Operations Management 32 (6), 357-373.

Benner, M.J., Tushman, M.L., 2002. Process management and technological innovation: A longitudinal study of the photography and paint industries. Administrative Science Quarterly 47 (4), 676-707.

Benner, M.J., Tushman, M.L., 2003. Exploitation, exploration, and process management: The productivity dilemma revisited. Academy of Management Review 28 (2), 238-256.

Bente, G., Rüggenberg, S., Krämer, N.C., Eschenburg, F., 2008. Avatar-mediated networking: Increasing social presence and interpersonal trust in net-based collaborations. Human Communication Research 34 (2) 287-318.

Bharati, P., Zhang, W., Chaudhury, A., 2015. Better knowledge with social media? Exploring the roles of social capital and organizational knowledge management. Journal of Knowledge Management 19 (3), 456-475.

Bills, S., 2007. BNY Mellon Pools Human Capital in Social Network. American Banker, November 9.

Blundell, R., Bond, S., 1998. Initial conditions and moment restrictions in dynamic panel data models. Journal of Econometrics 87 (1), 115-143.

Burson-Marsteller, 2011. The Global Social Media Check-up 2011. Burson-Marsteller, New York.

Burt, R.S., 1992. Structural Holes: The Social Structure of Competition. Harvard University Press, Cambridge, MA.

Burt, R.S., 2004. Structural holes and good ideas. American Journal of Sociology 110 (2), 349-399.

Cao, J., Basoglu, K.A., Sheng, H., Lowry, P.B., 2015. A systematic review of social networks research in information systems: Building a foundation for exciting future research. Communications of the Association for Information Systems 36 (1), 727-758.

Carter, S., 2012. Get Bold: Using Social Media to Create a New Type of Social Business. IBM Press, Upper Saddle River, NJ. 
Cassiman, B., Veugelers, R., 2006. In search of complementarily in innovation strategy: Internal R\&D and external knowledge acquisition. Management Science 52 (1), 68-82.

Cecere, L., 2010. Rise of Social Commerce: A Trail Guide for the Social Commerce Pioneer. Altimeter Group, San Mateo, CA.

Chevalier, J.A., Mayzlin, D., 2006. The effect of word of mouth on sales: Online book reviews. Journal of Marketing Research 43 (3), 345-354.

Chizema, A., Liu, X., Lu, J., Gao, L., 2015. Politically connected boards and top executive pay in Chinese listed firms. Strategic Management Journal 36 (6), 890-906.

Cho, H.J., Pucik, V., 2004. Reliability and validity of the Fortune Reputation Survey: Measuring innovativeness and quality. Working Paper 2004-6 IMD.

Cho, H.J., Pucik, V., 2005. Relationship between innovativeness, quality, growth, profitability, and market value. Strategic Management Journal 26 (6), 555-575.

Choo, A.S., Linderman, K.W., Schroeder, R.G., 2007. Method and context perspectives on learning and knowledge creation in quality management. Journal of Operations Management 25 (4), 918-931.

Chua, A.Y., Banerjee, S., 2013. Customer knowledge management via social media: the case of Starbucks. Journal of Knowledge Management, 17 (2), 237-249.

Cohen, W., Levinthal, D., 1990. Absorptive capacity: A new perspective on learning and innovation. Administrative Science Quarterly 35 (1), 128-152.

Cousins, P.D., Menguc, B., 2006. The implications of socialization and integration in supply chain management. Journal of Operations Management 24 (5), 604-620.

Crouse, P., Doyle, W., Young, J.D., 2011. Trends, roles, and competencies in human resource management practice: A perspective from practitioners in Halifax, Canada. The ASBBS Annual Conference, Las Vegas, NV.

Cui, A.S., O'Connor, G., 2012. Alliance portfolio resource diversity and firm innovation. Journal of Marketing 76 (4), 24-43.

Dahl, M.S., Pedersen, C.Ø., 2004. Knowledge flows through informal contacts in industrial clusters: 
Myth or reality?. Research Policy 33 (10), 1673-1686.

Dahlander, L., Frederiksen, L., 2012. The core and cosmopolitans: A relational view of innovation in user communities. Organization Science 23 (4), 988-1007.

Dehning, B., Richardson, V.J., Zmud, R.W., 2007. The financial performance effects of IT-based supply chain management systems in manufacturing firms. Journal of Operations Management 25 (4), 806-824.

Dezsö, C.L., Ross, D.G., 2012. Does female representation in top management improve firm performance? A panel data investigation. Strategic Management Journal 33 (9), 1072-1089.

Dou, Y., Niculescu, M.F., Wu, D.J., 2013. Engineering optimal network effects via social media features and seeding in markets for digital goods and services. Information Systems Research 24 (1), 164-185.

Dutta, S., Narasimhan, O.M., Rajiv, S., 2005. Conceptualizing and measuring capabilities: Methodology and empirical application. Strategic Management Journal 26 (3), 277-285.

Edwards, J., 2012. Meet the 30 Biggest Social Media Advertisers of 2012. Business Insider, New York.

Eng, T.Y., Quaia, G., 2009. Strategies for improving new product adoption in uncertain environments: A selective review of the literature. Industrial Marketing Management 38 (3), 275-282.

Epstein, J.D., 2011. Banks turning online rants into compliments. Buffalo News (January 30), P9.

Eroglu, C., Hofer, C., 2011. Lean, leaner, too lean? The inventory-performance link revisited. Journal of Operations Management 29 (4), 356-369.

Fader, P.S., Winer, R.S., 2012. Introduction to the special issue on the emergence and impact of user-generated content. Marketing Science 31 (3), 369-371.

Flannery, M.J., Hankins, K.W., 2013. Estimating dynamic panel models in corporate finance. Journal of Corporate Finance 19, 1-19.

Forman, C., Ghose, A., Wiesenfeld, B., 2008. Examining the relationship between reviews and sales: The role of reviewer identity disclosure in electronic markets. Information Systems Research 19 (3), 291-313. 
Gallaugher, J., Ransbotham, S., 2010. Social media and customer dialog management at Starbucks. MIS Quarterly Executive 9 (4), 197-212.

Gamboa, A.M., Gonçalves, H.M., 2014. Customer loyalty through social networks: Lessons from Zara on Facebook. Business Horizons 57 (6), 709-717.

Gassmann, O., 2001. Multicultural teams: Increasing creativity and innovation by diversity. Creativity and Innovation Management 10 (2), 88-95.

Gaudin, S., 2010. Experts warn of the dark side of enterprise 2.0. Computerworld, http://www.computerworld.com/article/2519038/social-business/experts-warn-of-the-dark-sideof-enterprise-2-0.html.

Gnyawali, D.R., Fan, W., Penner, J., 2010. Competitive actions and dynamics in the digital age: An empirical investigation of social networking firms. Information Systems Research 21 (3), 594-613.

Goulart, K., 2012. GE brings social collaboration to life with Colab. Enterprise CIO Decisions 15, 13-16.

Gu, B., Ye, Q., 2014. First step in social media: Measuring the influence of online management responses on customer satisfaction. Production and Operations Management 23 (4), 570-582.

Gutiérrez Gutiérrez, L.J., Bustinza, O.F., Molina, V.B., 2012. Six sigma, absorptive capacity and organisational learning orientation. International Journal of Production Research 50 (3), $661-675$.

Harvard Business Review Analytic Services, 2010. The New Conversation: Taking Social Media from Talk to Action. Harvard Business Review, Boston, MA.

Hendricks, K.B., Singhal, V.R., Zhang, R., 2009. The effect of operational slack, diversification, and vertical relatedness on the stock market reaction to supply chain disruptions. Journal of Operations Management 27 (3), 233-246.

Henschen, D., 2010. Wendy's taps text analytics to mine customer feedback. InformationWeek, http://www.informationweek.com/software/operating-systems/wendys-taps-text-analytics-to-mi ne-customer-feedback-/d/d-id/1087761. 
Hitt, M.A., Carnes, C.M., Xu, K., 2016a. A current view of resource based theory in operations management: A response to Bromiley and Rau. Journal of Operations Management 41, 107-109.

Hitt, M.A., Xu, K., Carnes, C.M., 2016b. Resource based theory in operations management research. Journal of Operations Management 41, 77-94.

Hult, G.T.M., Ketchen, D.J., Slater, S.F., 2004. Information processing, knowledge development, and strategic supply chain performance. Academy of Management Journal 47 (2), 241-253.

Jacobs, B.W., Swink, M., Linderman, K., 2015. Performance effects of early and late Six Sigma adoptions. Journal of Operations Management 36, 244-257.

Johnson, P.F., Klassen, R.D., Leenders, M.R., Awaysheh, A., 2007. Utilizing e-business technologies in supply chains: The impact of firm characteristics and teams. Journal of Operations Management 25 (6), 1255-1274.

Kahn, K.B., 2001. Market orientation, interdepartmental integration, and product development performance. Journal of Product Innovation Management 18 (5), 314-323.

Kane, G.C., Palmer, D., Phillips, A.N., Kiron, D., Buckley, N., 2014. Moving Beyond Marketing: Generating Social Business Value Across the Enterprise. MIT Sloan Management Review, Cambridge, MA.

Kankanhalli, A., Tan, B.C., Wei, K.K., 2005. Contributing knowledge to electronic knowledge repositories: An empirical investigation. MIS Quarterly 29 (1), 113-143.

Kaplan, A.M., Haenlein, M., 2010. Users of the world, unite! The challenges and opportunities of social media. Business Horizons 53 (1), 59-68.

Kim, D.Y., Kumar, V., Kumar, U., 2012. Relationship between quality management practices and innovation. Journal of Operations Management 30 (4), 295-315.

Kiron, D., Palmer, D., Phillips, A.N., Berkman, R., 2013. Social Business: Shifting Out of First Gear. MIT Sloan Management Review, Cambridge, MA.

Kiron, D., Palmer, D., Phillips, A.N., Kruschwitz, N., 2012. Social Business: What Are Companies Really Doing? MIT Sloan Management Review, Cambridge, MA. 
Kiviet, J.F., 1995. On bias, inconsistency, and efficiency of various estimators in dynamic panel data models. Journal of Econometrics 68 (1), 53-78.

Kortmann, S., Gelhard, C., Zimmermann, C., Piller, F.T., 2014. Linking strategic flexibility and operational efficiency: The mediating role of ambidextrous operational capabilities. Journal of Operations Management 32 (7), 475-490.

Koufteros, X., Vonderembse, M., Jayaram, J., 2005. Internal and external integration for product development: The contingency effects of uncertainty, equivocality, and platform strategy. Decision Sciences 36 (1), 97-133.

Kusunoki, K., Nonaka, I., Nagata, A., 1998. Organizational capabilities in product development of Japanese firms: A conceptual framework and empirical findings. Organization Science 9 (6), 699-718.

Kwong, W.J., Norton, E.C., 2007. The effect of advertising on pharmaceutical innovation. Review of Industrial Organization 31 (3), 221-236.

Leonardi, P.M., 2007. Activating the informational capabilities of information technology for organizational change. Organization Science 18 (5), 813-831.

Leonardi, P.M., 2014. Social media, knowledge sharing, and innovation: Toward a theory of communication visibility. Information Systems Research 25 (4), 796-816.

Leonardi, P.M., Huysman, M., Steinfield, C., 2013. Enterprise social media: Definition, history, and prospects for the study of social technologies in organizations. Journal of Computer-Mediated Communication 19 (1), 1-19.

Lesser, E. Prusak, L., 2000. Communities of practice, social capital, and organizational knowledge. In E. Lesser, M.A. Fontaine, J.A. Slusher, (Eds.), Knowledge and Communities, Butterworth-Heinemann, Boston, MA, 123-131.

Levin, D.Z., Cross, R., 2004. The strength of weak ties you can trust: The mediating role of trust in effective knowledge transfer. Management Science 50 (11), 1477-1490.

Li, E.Y., Loh, S., Evans, C., Lorenzi, F., 2013. Organizations and Social Networking: Utilizing Social Media to Engage Consumers. IGI Global, Hershey, PA. 
Li, S., Shang, J., Slaughter, S.A., 2010. Why do software firms fail? Capabilities, competitive actions, and firm survival in the software industry from 1995 to 2007. Information Systems Research 21 (3), 631-654.

Li, Y.M., Chen, H.M., Liou, J.H., Lin, L.F., 2014. Creating social intelligence for product portfolio design. Decision Support Systems 66, 123-134.

Lou, D., 2014. Attracting investor attention through advertising. Review of Financial Studies, 27 (6), $1797-1829$.

Luo, X., Zhang, J., Duan, W., 2013. Social media and firm equity value. Information Systems Research 24 (1), 146-163.

Martin, A., van Bavel, R., 2013. Assessing the Benefits of Social Networks for Organizations. Publications Office of the European Union, Luxembourg.

Martini, A., Massa, S., Testa, S., 2014. Customer co-creation projects and social media: The case of Barilla of Italy. Business Horizons 57 (3), 425-434.

Molina, L.M., Lloréns-Montes, J., Ruiz-Moreno, A., 2007. Relationship between quality management practices and knowledge transfer. Journal of Operations Management 25 (3), 682-701.

Molok, N.N.A., Chang, S., Ahmad, A., 2010. Information leakage through online social networking: Opening the doorway for advanced persistence threats. The 8th Australian Information Security Management Conference, Perth, Australia.

Mukherji, P., Sorescu, A., Prabhu, J.C., Chandy, R.K., 2011. Behemoths at the gate: How incumbents take on acquisitive entrants (and why some do better than others). Journal of Marketing 75 (5), $53-70$.

Nguyen, B., Yu, X., Melewar, T.C., Chen, J., 2015. Brand innovation and social media: Knowledge acquisition from social media, market orientation, and the moderating role of social media strategic capability. Industrial Marketing Management 51, 11-25.

Oettl, A., Agrawal, A., 2008. International labor mobility and knowledge flow externalities. Journal of International Business Studies, 39 (8), 1242-1260.

Peng, D.X., Schroeder, R.G., Shah, R., 2008. Linking routines to operations capabilities: A new 
perspective. Journal of Operations Management 26 (6), 730-748.

Pirinsky, C., Wang, Q., 2006. Does corporate headquarters location matter for stock returns?. Journal of Finance 61 (4), 1991-2015.

Piskorski, M.J., 2011. Social strategies that work. Harvard Business Review 89 (11), 116-122.

PR Newswire, 2012. Spredfast to provide Caterpillar with social engagement across the enterprise. http://www.prnewswire.com/news-releases/spredfast-to-provide-caterpillar-with-social-engage ment-across-the-enterprise-183906251.html.

Qualman, E., 2010. Socialnomics: How Social Media Transforms the Way We Live and Do Business. Wiley, New York.

Rabinovich, E., Dresner, M.E., Evers, P.T., 2003. Assessing the effects of operational processes and information systems on inventory performance. Journal of Operations Management 21 (1), 63-80.

Rishika, R., Kumar, A., Janakiraman, R., Bezawada, R., 2013. The effect of customers' social media participation on customer visit frequency and profitability: An empirical investigation. Information Systems Research 24 (1), 108-127.

Rodan, S., Galunic, D.C., 2004. More than network structure: How knowledge heterogeneity influences managerial performance and innovativeness. Strategic Management Journal 25, $541-556$.

Roodman, D., 2009. How to do xtabond2: An introduction to difference and system GMM in Stata. Stata Journal 9 (1), 86-136.

Sanders, N.R., 2007. An empirical study of the impact of e-business technologies on organizational collaboration and performance. Journal of Operations Management 25 (6), 1332-1347.

Schroeder, R.G., Linderman, K., Liedtke, C., Choo, A.S., 2008. Six Sigma: Definition and underlying theory. Journal of Operations Management 26 (4), 536-554.

Sodero, A.C., Rabinovich, E., Sinha, R.K., 2013. Drivers and outcomes of open-standard interorganizational information systems assimilation in high-technology supply chains. Journal of Operations Management 31 (6), 330-344. 
Staw, B.M., Epstein, L.D., 2000. What bandwagons bring: Effects of popular management techniques on corporate performance, reputation, and CEO pay. Administrative Science Quarterly 45 (3), 523-556.

Subramaniam, M., Youndt, M.A., 2005. The influence of intellectual capital on the types of innovative capabilities. Academy of Management Journal 48 (3), 450-463.

Szulanski, G., 1996. Exploring internal stickiness: Impediments to the transfer of best practice within the firm. Strategic Management Journal 17 (S2), 27-43.

Tanriverdi, H., 2005. Information technology relatedness, knowledge management capability, and performance of multibusiness firms. MIS Quarterly 29 (2), 311-334.

Thomas, K.J., Akdere, M., 2013. Social media as collaborative media in workplace learning. Human Resource Development Review 12 (3), 329-344.

Treem, J.W., Leonardi, P.M., 2012. Social media use in organizations: Exploring the affordances of visibility, editability, persistence, and association. Communication Yearbook 36, 143-189.

Tsai, W., 2001. Knowledge transfer in intraorganizational networks: Effects of network position and absorptive capacity on business unit innovation and performance. Academy of Management Journal 44 (5), 996-1004.

Tuertscher, P., Garud, R., Kumaraswamy, A., 2014. Justification and interlaced knowledge at ATLAS, CERN. Organization Science 25 (6), 1579-1608.

Vaidyanathan, G., Devaraj, S., 2008. The role of quality in e-procurement performance: An empirical analysis. Journal of Operations Management 26 (3), 407-425.

Vandaie, R., Zaheer, A., 2014. Alliance partners and firm capability: Evidence from the motion picture industry. Organization Science 26 (1), 22-36.

Wade, M., Hulland, J., 2004. The resource-based view and information systems research: Review, extension, and suggestions for future research. MIS Quarterly 28 (1), 107-142.

Wintoki, M.B., Linck, J.S., Netter, J.M., 2012. Endogeneity and the dynamics of internal corporate governance. Journal of Financial Economics 105 (3), 581-606.

Wu, L., 2013. Social network effects on productivity and job security: Evidence from the adoption of 
a social networking tool. Information Systems Research 24 (1), 30-51.

Wu, S.J., Melnyk, S.A., Flynn, B.B., 2010. Operational capabilities: The secret ingredient. Decision Sciences 41 (4), 721-754.

Yli-Renko, H., Autio, E., Sapienza, H.J., 2001. Social capital, knowledge acquisition, and knowledge exploitation in young technology-based firms. Strategic Management Journal 22 (6-7), $587-613$.

Zhang, G.P., Xia, Y., 2013. Does quality still pay? A reexamination of the relationship between effective quality management and firm performance. Production and Operations Management $22(1), 120-136$. 


\section{Table 1}

A sample of social media initiatives.

\begin{tabular}{|c|c|c|c|}
\hline Category & Example & Date & Text extracted from Factiva \\
\hline & $\begin{array}{l}\text { Unisys Corp } \\
\text { (UIS) }\end{array}$ & $\begin{array}{l}11 \\
\text { Dec } \\
2010\end{array}$ & $\begin{array}{l}\text { At Unisys, we have launched My site earlier this year, which is our } \\
\text { equivalent of Facebook. What has happened because of this is, all } \\
\text { our employees across the world have a platform to talk about the } \\
\text { work they are doing, ask questions to each other, and share best } \\
\text { practices. My site has been giving employees constant access to } \\
\text { everyone, including top management. }\end{array}$ \\
\hline $\begin{array}{l}\text { Employee } \\
\text { Collaboration } \\
\text { and Internal } \\
\text { Communication }\end{array}$ & $\begin{array}{l}\text { ConocoPhillips } \\
\text { (COP) }\end{array}$ & $\begin{array}{l}23 \\
\text { Mar } \\
2009\end{array}$ & $\begin{array}{l}\text { The Houston-based ConocoPhillips has developed about } 100 \text { online } \\
\text { knowledge sharing networks, which are used by about } 9,500 \text {, or } \\
28 \% \text { of its worldwide employees to post questions and find answers } \\
\text { from colleagues. }\end{array}$ \\
\hline
\end{tabular}

Honeywell 18 Apr Connectbeam, Inc., a leading provider of enterprise social software, (HON) 2007 announced today that it has been chosen by global technology company Honeywell (NYSE: HON) to provide social bookmarking and tagging, expertise location, and enterprise social networking capabilities to Honeywell employees. Using Connectbeam software, Honeywell knowledge workers will be able to locate and manage information together while easily networking with each other's knowledge, interests and skills in a secure, behind the firewall implementation.

Arrow

Electronics

(ARW)

Interfirm

Cooperation and Supply

Chain

Management

\section{General}

Electric

(GE)

11 Feb
2011

\section{Assisting reselle}

collaborating on sales opportunities and building relationships with other resellers, system integrators and other solution providers, Arrow Enterprise Computing Solutions, a business segment of Arrow Electronics Inc., launched a social networking site called Virtual Bench initially for its North American IBM channel community. Over time, the network will be continually extended to include other Arrow ECS supplier lines.

24 Just as LinkedIn was developed for professional networking, and May Facebook for social networking, Aravo Assure (TM) was developed 2011 to harness the power of collaborative networks to drive more efficient, effective business-to-business relationships for companies of all sizes. Starting this month, GE will provide access to Aravo Assure(TM) to its 750,000 suppliers to simplify processes and data requirements associated with selling goods and services to GE.

American

$28 \mathrm{Jul}$ American Express Business Travel announced plans to launch a Express 2008 (AXP)

Dell

(DELL)

16 Feb

business-to-business online networking community for the corporate travel industry. A first-of-its-kind resource, BusinessTravelConnexion.com will bring together a consortium of industry decision makers, suppliers, and experts in the industry's most extensive online, community platform.

At Dell IdeaStorm (www.dellideastorm.com), users are asked to post ideas for new products and feedback on current Dell offerings. Users can rate ideas, using a voting function similar to popular social news site Digg. Dell said it would use some of that feedback in developing new products.

New Product Development and Idea

Deutsche Bank 14 Oct Deutsche Bank's global transaction business unit announced it is Generation introducing an online community forum where clients can engage with bank staff in the development of new products. With the theme "Drive DB!", the Web 2.0-based community site lets clients participate in steering product design and development through online voting, debates and information sharing with other clients and with product, sales and service experts at Deutsche Bank.

Hyundai $9 \mathrm{Feb}$ Hyundai Motor America today announced it has partnered with Motor 2009 Passenger, the technology leader in on-demand Customer 
(HYMTF) Collaboration, to create the "Hyundai Think Tank," a private online community for Hyundai owners. Hyundai Think Tank members will help shape the future of the brand and new products through online discussions, facilitated meetings with executives and other activities.

Sears $24 \quad$ In its latest initiative to support America's military members, Sears

(SHLD) Aug has teamed with Rebuilding Together to conduct "Operation Rebuild

2011 for Heroes at Home," a social media contest that gives communities across the U.S. the opportunity to help servicemen and women in need.

Merck 10 Feb Merck Serono, a division of Merck, today announced the launch of

Public

(MRK)

Relations and

Corporate

Social

Responsibility

Western Union (WU)
2011 UniteMS.net, a groundbreaking international social network designed specifically for people living with and affected by multiple sclerosis (MS) around the world. UniteMS is intended to offer a digital venue for the MS community to empower themselves through best in class information, gain inspiration from worldwide stories of hope, and explore a trusted environment with the most and easiest avenues to communicate with peers.

27 Oct The Western Union Company (NYSE:WU) and the Western Union 2008 Foundation today announced the launch of a new online platform for social giving, 'Our World Gives': http://apps.facebook.com/ourworldgives. Aimed at reaching the 18 million members of the Facebook social networking site, the program seeks to increase awareness of critical social issues and charitable community spirit.

Delta Air Lines 30 Jun Delta Air Lines is expanding its use of social media as a customer (DAL) $\quad 2010$ service tool, launching a pilot program this month with a five-person team to respond to customer concerns sent to the airline on Twitter.

Customer

Service and Customer

Royal Bank of 16 Scotland Nov

Relationship (RBS)

2011

Management

Vodafone

26 Oct

(VOD)

The Royal Bank of Scotland group is turning to social media to expand its 'helpful banking' positioning, with a social CRM initiative that will allow consumers to give feedback on banking with its NatWest and RBS chains. capture the increasing number of social media communications the telco is experiencing with its customer base. The new system, as part of the telco's 'One Connect' strategy, will seek to capture tweets and Facebook messages along with more traditional email, voice and SMS-based customer enquiries.

Delta Air Lines 12 Delta Air Lines Inc. said Thursday it's launched a new "Ticket

(DAL) Aug Window" on Facebook that will allow passengers to book directly

2010 on the social media site. It's the first time an airline has allowed customers to reserve flights on Facebook.

Live Nation 23 Jan Live Nation announced that it has signed a deal with the internet's (LYV) 2007 social music network, Last.fm, agreeing to provide the music fan website with U.S. and Canadian concert information from LiveNation.com. The direct feed to Last.fm will give music fans instant access to concert information, as well as links to purchase tickets.

Walt Disney 03 Jun The Walt Disney Co. has created what it believes is a (DIS) $\quad 2010$ first-of-its-kind application allowing Facebook users to buy tickets to Toy Story 3 without leaving the social networking site and while, at the same time, prodding their friends to come along. The application, called Disney Tickets Together, could transform how Hollywood sells movie tickets by interweaving purchases with the forces of social networking. 


\section{Table 2}

Summary information on performance measures and social media initiatives.

\begin{tabular}{|c|c|c|}
\hline & Operational Efficiency & Innovativeness \\
\hline Number of sample firms & 281 & 281 \\
\hline Sample periods for dependent variables & 7 years $(2006-2012)$ & 7 years $(2006-2012)$ \\
\hline \multirow[t]{2}{*}{ [no. of two-year consecutive data obtained] } & [i.e., 6 two-year & [i.e., 6 two-year \\
\hline & consecutive data] & consecutive data $]$ \\
\hline Total number of consecutive firm-years with consecutive & 1,686 (281 firms x 6 & $1,686(281$ firms x 6 \\
\hline data & years) & years) \\
\hline No. of effective firm-years with available consecutive & 1,159 out of 1,686 & 1,125 out of 1,686 \\
\hline data & $(68.7 \%)$ & $(66.7 \%)$ \\
\hline $\begin{array}{l}\text { Sample time periods for independent variable (i.e., social } \\
\text { media initiatives) }\end{array}$ & 6 years $(2006-2011)$ & 6 years $(2006-2011)$ \\
\hline Total number of social media initiatives from 2006-2011 & 841 announcements & 841 announcements \\
\hline Total number of social media initiatives in the effective & 730 announcements in & 690 announcements in \\
\hline firm-years & 1,159 firm-years & 1,125 firm-years \\
\hline Average number of initiatives per firm per year in the & 0.629 (ranged from 0 & 0.613 (ranged from 0 \\
\hline effective firm-years & to 30$)$ & to 30$)$ \\
\hline Number of firm-years with at least one initiative in the & 320 out of 1,159 & 310 out of 1,125 \\
\hline effective firm-years & $(27.61 \%)$ & $(27.55 \%)$ \\
\hline
\end{tabular}


Table 3

Descriptive statistics of sample firms.

\begin{tabular}{|c|c|c|c|c|c|}
\hline \multicolumn{6}{|c|}{ Panel A: The distribution of sample firms across industries } \\
\hline 2-digit SIC codes & \multicolumn{2}{|l|}{ Industries } & Firm frequency & \multicolumn{2}{|c|}{ Firm percentage } \\
\hline 36 & \multicolumn{2}{|c|}{ Electronic \& other electric equipment } & 27 & \multicolumn{2}{|r|}{$9.6 \%$} \\
\hline 73 & \multicolumn{2}{|c|}{ Business services } & 27 & \multicolumn{2}{|r|}{$9.6 \%$} \\
\hline 28 & \multicolumn{2}{|c|}{ Chemical \& allied products } & 25 & \multicolumn{2}{|r|}{$8.9 \%$} \\
\hline 35 & \multicolumn{2}{|c|}{ Industrial machinery \& equipment } & 24 & \multicolumn{2}{|r|}{$8.5 \%$} \\
\hline 37 & \multicolumn{2}{|c|}{ Transportation equipment } & 15 & \multicolumn{2}{|r|}{$5.3 \%$} \\
\hline 38 & \multicolumn{2}{|c|}{ Instruments \& related products } & 15 & \multicolumn{2}{|r|}{$5.3 \%$} \\
\hline 20 & \multicolumn{2}{|c|}{ Food \& kindred products } & 12 & \multicolumn{2}{|r|}{$4.3 \%$} \\
\hline 50 & \multicolumn{2}{|c|}{ Wholesale trade - durable goods } & 11 & \multicolumn{2}{|r|}{$3.9 \%$} \\
\hline 53 & \multicolumn{2}{|c|}{ General merchandise stores } & 11 & \multicolumn{2}{|r|}{$3.9 \%$} \\
\hline 26 & \multicolumn{2}{|c|}{ Paper \& allied products } & 9 & \multicolumn{2}{|r|}{$3.2 \%$} \\
\hline 51 & \multicolumn{2}{|c|}{ Wholesale trade - nondurable goods } & 9 & \multicolumn{2}{|r|}{$3.2 \%$} \\
\hline 80 & \multicolumn{2}{|c|}{ Health services } & 8 & \multicolumn{2}{|r|}{$2.8 \%$} \\
\hline 25 & \multicolumn{2}{|c|}{ Furniture \& fixtures } & 7 & \multicolumn{2}{|r|}{$2.5 \%$} \\
\hline 56 & Apparel \& accessor & tores & 7 & & $2.5 \%$ \\
\hline 58 & Eating \& drinking & & 7 & & $2.5 \%$ \\
\hline 63 & Insurance carri & & 6 & & $2.1 \%$ \\
\hline 33 & Primary metal ind & & 5 & & $1.8 \%$ \\
\hline 48 & Communicatio & & 5 & & $1.8 \%$ \\
\hline 54 & Food stores & & 4 & & $1.4 \%$ \\
\hline 79 & Amusement \& recreati & services & 4 & & $1.4 \%$ \\
\hline Other SIC codes & Other industri & & 43 & & $15.3 \%$ \\
\hline & Panel B: The cha & teristics of $\mathrm{s}$ & ple firms & & \\
\hline Variable & Unit & Mean & Std. deviation & Minimum & Maximum \\
\hline Sales & Millions of dollars & 30362.34 & 53309.11 & 1318.80 & 444948.00 \\
\hline Total assets & Millions of dollars & 34084.31 & 72599.20 & 487.50 & 797769.00 \\
\hline Operating income & Millions of dollars & 4678.65 & 8651.23 & 5.00 & 78669.00 \\
\hline Number of employees & Thousands & 81.92 & 166.46 & 1.02 & 2200.00 \\
\hline Cost of goods sold & Millions of dollars & 20602.57 & 41232.78 & 80.30 & 359806.16 \\
\hline Capital expenditure & Millions of dollars & 1463.70 & 3635.29 & 3.66 & 30975.00 \\
\hline Return on assets & Ratio & 0.15 & 0.07 & 0.00 & 0.63 \\
\hline Age & Years & 65.91 & 45.20 & 1.00 & 209.00 \\
\hline $\mathrm{R} \& \mathrm{D}$ expense & Millions of dollars & 916.66 & 1805.31 & 0.00 & 10991.00 \\
\hline Advertising expense & Millions of dollars & 684.50 & 1182.78 & 0.60 & 9315.00 \\
\hline
\end{tabular}




\section{Table 4}

Correlation matrix.

\begin{tabular}{|c|c|c|c|c|c|c|c|c|c|c|}
\hline Variable & 1. & 2. & 3. & 4. & 5. & 6. & 7. & 8. & 9. & 10. \\
\hline 1. Operational Efficiency & 1 & & & & & & & & & \\
\hline 2. Lagged Operational Efficiency & $0.799 * *$ & 1 & & & & & & & & \\
\hline 3. Innovativeness & $0.178 * *$ & $0.184 * *$ & 1 & & & & & & & \\
\hline 4. Lagged Innovativeness & $0.174 * *$ & $0.186 * *$ & $0.798 * *$ & 1 & & & & & & \\
\hline 5. Social Media Initiatives & $0.120 * *$ & $0.108 * *$ & $0.121 * *$ & $0.088 * *$ & 1 & & & & & \\
\hline 6. Firm Size & $0.062 *$ & $0.066^{*}$ & $0.261 * *$ & $0.237 * *$ & $0.215^{* *}$ & 1 & & & & \\
\hline 7. Firm Profitability & $0.508 * *$ & $0.399 * *$ & $0.099 * *$ & $0.104 * *$ & 0.046 & 0.007 & 1 & & & \\
\hline 8. Firm Age & 0.045 & $0.062 *$ & 0.056 & 0.057 & -0.026 & $0.145 * *$ & -0.023 & 1 & & \\
\hline 9. Firm R\&D Intensity & $0.302 * *$ & $0.298 * *$ & 0.053 & $0.067 *$ & 0.008 & $-0.095 * *$ & $0.062 *$ & -0.042 & 1 & \\
\hline 10. Firm Advertising Expense & $0.120 * *$ & $0.149 * *$ & $0.116 * *$ & $0.110 * *$ & $0.115 * *$ & $0.555 * *$ & 0.048 & $0.264 * *$ & $0.109 * *$ & 1 \\
\hline Mean & 0.668 & 0.668 & 0.226 & 0.208 & 0.070 & 9.599 & 0.147 & 3.937 & 0.044 & 5.536 \\
\hline Standard Deviation & 0.107 & 0.108 & 0.931 & 0.923 & 1.129 & 1.180 & 0.067 & 0.807 & 0.066 & 1.692 \\
\hline
\end{tabular}

$* p<0.05, * * p<0.01$. 


\section{Table 5}

The impact of social media initiatives on operational efficiency.

\begin{tabular}{|c|c|c|}
\hline Variable & System GMM & OLS \\
\hline Intercept & $\begin{array}{c}0.715 * * \\
(2.611)\end{array}$ & $\begin{array}{c}0.212 * * \\
(6.425)\end{array}$ \\
\hline Lagged Operational Efficiency & $\begin{array}{c}0.153 * * \\
(3.701)\end{array}$ & $\begin{array}{l}0.607 * * \\
(13.714)\end{array}$ \\
\hline Social Media Initiatives & $\begin{array}{l}0.003 * \\
(2.417)\end{array}$ & $\begin{array}{l}0.002 * \\
(2.239)\end{array}$ \\
\hline Firm Size & $\begin{array}{c}-0.005 \\
(-0.222)\end{array}$ & $\begin{array}{c}0.005 \\
(1.936)\end{array}$ \\
\hline Firm Profitability & $\begin{array}{c}1.049 * * \\
(9.776)\end{array}$ & $\begin{array}{c}0.464 * * \\
(8.260)\end{array}$ \\
\hline Firm Age & $\begin{array}{c}-0.058 \\
(-1.771)\end{array}$ & $\begin{array}{c}0.001 \\
(0.282)\end{array}$ \\
\hline Firm R\&D Intensity & $\begin{array}{c}-0.214 \\
(-1.238)\end{array}$ & $\begin{array}{l}0.169 * \\
(2.501)\end{array}$ \\
\hline Firm Advertising Expense & $\begin{array}{c}-0.010 \\
(-0.909)\end{array}$ & $\begin{array}{c}-0.001 \\
(-0.546)\end{array}$ \\
\hline Year Dummies & Included & Included \\
\hline Industry Dummies & Included & Included \\
\hline Number of firm-year observations & 1159 & 1159 \\
\hline Wald Chi-square & $217.38 * *$ & \\
\hline Sargan statistic & $p=0.42$ & \\
\hline $\operatorname{AR}(1)$ & $p=0.03$ & \\
\hline $\operatorname{AR}(2)$ & $p=0.56$ & \\
\hline$R$-squared & & 0.72 \\
\hline$F$-value & & $65.89 * *$ \\
\hline
\end{tabular}

Notes:

1. $* p<0.05, * * p<0.01$.

2 . $t$-statistics are in parentheses. 


\section{Table 6}

The impact of social media initiatives on innovativeness.

\begin{tabular}{|c|c|c|}
\hline Variable & System GMM & OLS \\
\hline Intercept & $\begin{array}{c}-2.612 \\
(-1.243)\end{array}$ & $\begin{array}{c}-0.917 * * \\
(-3.523)\end{array}$ \\
\hline Lagged Innovativeness & $\begin{array}{l}0.131 * \\
(2.339)\end{array}$ & $\begin{array}{l}0.759 * * \\
(40.282)\end{array}$ \\
\hline Social Media Initiatives & $\begin{array}{c}0.036 * * \\
(2.657)\end{array}$ & $\begin{array}{l}0.030 * \\
(2.322)\end{array}$ \\
\hline Firm Size & $\begin{array}{l}0.331 * \\
(2.221)\end{array}$ & $\begin{array}{c}0.074 * * \\
(3.121)\end{array}$ \\
\hline Firm Profitability & $\begin{array}{c}0.276 \\
(0.357)\end{array}$ & $\begin{array}{l}0.600 * \\
(2.102)\end{array}$ \\
\hline Firm Age & $\begin{array}{c}0.045 \\
(0.089)\end{array}$ & $\begin{array}{c}-0.006 \\
(-0.214)\end{array}$ \\
\hline Firm R\&D Intensity & $\begin{array}{c}0.738 \\
(1.285)\end{array}$ & $\begin{array}{c}0.366 \\
(1.076)\end{array}$ \\
\hline Firm Advertising Expense & $\begin{array}{c}-0.117 \\
(-1.585)\end{array}$ & $\begin{array}{c}-0.005 \\
(-0.328)\end{array}$ \\
\hline Year Dummies & Included & Included \\
\hline Industry Dummies & Included & Included \\
\hline Number of firm-year observations & 1125 & 1125 \\
\hline Wald Chi-square & $32.38 *$ & \\
\hline Sargan statistic & $p=0.34$ & \\
\hline $\operatorname{AR}(1)$ & $p=0.00$ & \\
\hline $\operatorname{AR}(2)$ & $p=0.24$ & \\
\hline$R$-squared & & 0.66 \\
\hline$F$-value & & $64.74 * *$ \\
\hline
\end{tabular}

Notes:

1. $* p<0.05, * * p<0.01$.

2 . $t$-statistics are in parentheses. 
Table 7

Difference-in-difference results.

\begin{tabular}{lllll}
\hline & Difference-in-difference & $N$ & $t$-statistics & $p$-value \\
\hline Operational Efficiency & 0.005 & 315 & 2.097 & 0.037 \\
Innovativeness & 0.120 & 300 & 3.840 & 0.000 \\
\hline
\end{tabular}

Figure 1

The conceptual framework of our research.

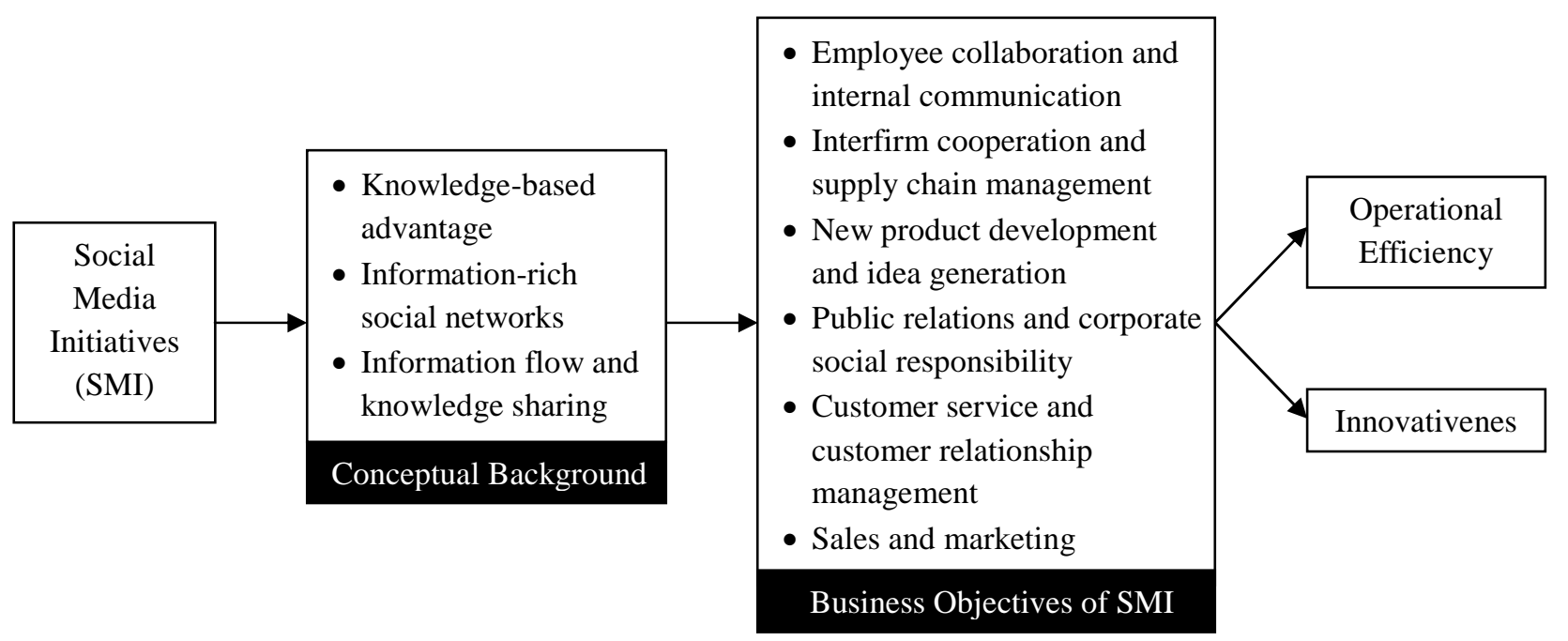




\section{Appendix}

A social media initiative announcement extracted from Factiva.

DOW JONES

Honeywell Chooses Connectbeam for Social Bookmarking and Social Networking; New social software allows enterprise users to connect and collaborate on demand

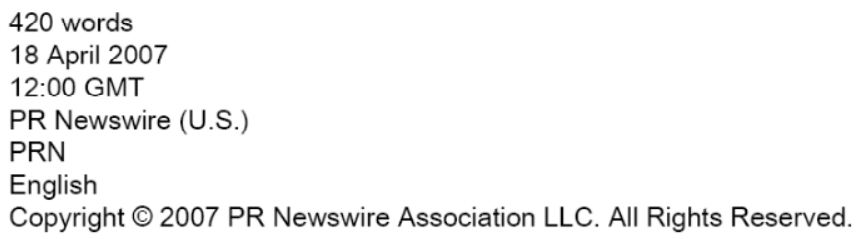

REDWOOD CITY, Calif., April 18 /PRNewswire/ -- Connectbeam, Inc., a leading provider of enterprise social software, announced today that it has been chosen by global technology company Honeywell (NYSE: HON) to provide social bookmarking and tagging, expertise location, and enterprise social networking capabilities to Honeywell employees. Using Connectbeam software, Honeywell knowledge workers will be able to locate and manage information together while easily networking with each other's knowledge, interests and skills in a secure, behind the firewall implementation.

Honeywell's implementation is based on Connectbeam's Social Bookmarking \& Networking Appliance, a pre-configured appliance server deployed behind the enterprise firewall, and Connectbeam's Application Connector for Google Enterprise Search.

Honeywell's $\quad * \quad$ has posted about the Connectbeam implementation at http://econtent.typepad.com/econtent/2007/03/tagging_inside_html.

* Connectbeam's CEO, commented, "Connectbeam solves two key problems facing every enterprise worker: how to find information that they can be certain is current, accurate and significant, and how to locate and connect with knowledgeable colleagues."

"Connectbeam's integration with Google Enterprise Search was important to Honeywell," added Connectbeam Vice President of Sales, * * "By making Google search results more useful, Connectbeam helps Honeywell employees do better, more efficient work, while improving the company's ROI on its Google search investment."

Integration with enterprise search, from Google and a number of other vendors, allows Connectbeam to provide social search. Search results now highlight information from your colleagues' searches, especially the information that they have found most useful. Connectbeam also points the user to related searches that can extend knowledge. Most important, Connectbeam social search instantly and effortlessly identifies and connects enterprise workers with colleagues whose interests and knowledge enhances theirs. Connectbeam integration means that every enterprise search increases collective intelligence and makes it easily available to enterprise workers.

About Connectbeam: Connectbeam is a leading provider of Enterprise 2.0 social software, bringing Web 2.0 information-sharing and ease of use to the enterprise, so that organizations and their employees can connect and collaborate on demand. Privately held, Connectbeam is located in California's Silicon Valley. More information about Connectbeam and its offerings can be found at http://www.connectbeam.com.

SOURCE Connectbeam, Inc.

200704180800PR_NEWS_USPR SFW006.xml

Document PRN0000020070418e34i003ms

Page 1 of 1 (0) 2014 Factiva, Inc. All rights reserved.

*Name deleted for confidentiality. 